\title{
Totalitaryzm - doświadczenie i konceptualizacja językowa. Obraz pojęcia w języku polityki okresu drugiej wojny światowej
}

\section{Ustalenia wstępne}

1. Zjawiska totalitaryzmu czy propagandy totalitarnej doczekały się obszernych interdyscyplinarnych studiów, co wynika między innymi z historii XX wie$\mathrm{ku}$, a ściśle mówiąc — z tragicznych następstw władzy o cechach tyranii. Powstanie i upadek monopolistycznych systemów politycznych, a przede wszystkim ich wpływ na tragiczne wydarzenia w najnowszej historii europejskiej oraz równie tragiczne doświadczenia społeczeństw (narodów) żyjących w realiach totalitarnego państwa i ofiar zbrodni wojennych, ludobójstwa (w tym przede wszystkim Zagłady), spowodowały, że na temat totalitaryzmu i zjawisk społecznych z nim tożsamych wypowiadali się przedstawiciele różnych dyscyplin badań humanistycznych i społecznych. Można nawet zaryzykować tezę, że totalitaryzm po części wywarł wpływ na rozwój nowoczesnych szkół psychologicznych, socjologicznych czy medioznawczych (por. Doliński, Gamian-Wilk 2014; Jakubowska-Branicka 2013). Od lat 20. XX wieku próbowano bowiem odpowiedzieć na pytanie, jakie mechanizmy socjotechniczne doprowadzają do tego, że ludzie ulegają ideologii, propagandzie i kultowi władzy totalitarnej.

Dzisiejsze szkoły krytycznej analizy dyskursu (Wodak 2008, 2011), ujawniające różne patologie komunikacji społecznej, a przede wszystkim źródła retoryki nienawiści (por. Głowiński 1996, 2002, 2007; Butler 2010; Linde-Usiekniewicz 2015; Cegieła 2014 i in.), sięgają po narzędzia badawcze wykorzystane przez pierwszych obserwatorów — naocznych świadków przemian (niektórych) demokratycznych systemów politycznych w międzywojennej Europie w dyktatury i reżimy (zob. Besier, Stokłosa 2009). 
Choć lingwistyka zajmująca się komunikacją polityczną i medialną wypracowała metody badań relewantne do zjawisk we współczesnych dyskursach publicznych, nadal, opisując najważniejsze dla nich mechanizmy komunikacyjne na pograniczu propagandy, kłamstwa, manipulacji, odnosi się do uniwersaliów retorycznych, pragmatycznych i socjotechnicznych charakterystycznych dla języka w komunikacji totalitarnej (por. Karwat 2014a, b). Co więcej, niekiedy aberracyjne zjawiska w dyskursie politycznym tłumaczone są $\mathrm{w}$ kategoriach „paranoi politycznej” (Robins, Post 2007; por. Korzeniowski 2010; Jakubowska-Branicka 2013) lub „politycznej religii” (termin Raymonda Arona, zob. m.in. Besier 2010; Gross 2002; Bäcker 1992; Bankowicz 2010; Olszewska-Dyoniziak 1999), a więc terminologii, która wprawdzie wywodzi się z psychologii społecznej, określającej zjawisko narodzin rządów dyktatorskich i skrajnej socjotechniki operującej językiem uproszczeń, demagogii i agresji, ale może również dotyczyć odstępstw w każdej kulturze politycznej, jej przemian: z uczestniczącej (wielogłosowej) w kierunku poddańczej (monologowej) ${ }^{1}$.

Bardzo niepokojące są konstatacje zawarte w tych wielu opracowaniach, że historia totalitaryzmów to ostrzeżenie dla wszystkich (zob. m.in. Kershaw 2016; Snyder 2017; Albright 2018), gdyż reżimy i dyktatury z początku XX wieku upadły, ale rządy totalitarne w niektórych krajach trwają nadal, a mechanizmy społeczne i wizje polityki, które burzyły spokój w Europie dwudziestolecia, mogą się łatwo odradzać, co też ma swoje przełożenie na poziom refleksji o kulturze politycznej.

2. Artykuł ten powstał z chęci wypełnienia luki w badaniach nad językiem (dyskursem) politycznym, a główną inspiracją stały się opracowania podejmujące tematykę przemian słownictwa społeczno-politycznego na przełomie XIX i XX wieku (m.in. Karamańska 2007; Dubisz, Porayski-Pomsta, Sękowska (red.) 2004, 2007). Pierwszy powód tłumaczyć można ciągle ubogim stanem badań nad komunikacją polityczną czy dyskursem politycznym lat 1939-1945 w porównaniu z całościowym spojrzeniem na język polityki XX wieku². Drugi powód został już zasygnalizowany we wstępie: chodzi o opis dziejów nazwy totalizm/totalitaryzm, a także słownictwa sytuującego się w polu leksykalno-semantycznym, dla którego wskazany wyraz jest hiperonimem. O ile termin totalizm, oznaczający system rządów reżimowych, wchodził do polszczyzny pod koniec lat 30 . XX wieku, bezpośrednio przed wybuchem drugiej wojny światowej, o tyle bardzo szybko proces nazwotwórczy uległ różnym semantycznym (głównie konotacyjnym) modyfikacjom w czasie realnego spotkania z brutalną rzeczywistośią okupacyjną i totalitarną.

${ }^{1}$ O pojęciu „kultura polityczna” i jej klasyfikacjach, nawiązujących do teorii Gabriela Almonda i Sidneya Verba, a przede wszystkim o wpływie dominującej kultury politycznej na dyskurs polityczny więcej w Kamińska-Szmaj (2007, 2013), zob. także Fras (2006); Besier, Stokłosa (2009).

2 O stanie badań nad językiem polityki w latach 1939-1945 w przeglądzie I. Kamińskiej-Szmaj (2013: 417-419), a opis wybranych zjawisk głównie w pracach: O. Wolińskiej (1992, 1996), E. Jędrzejko (1996), zawartych w tomie pod red. I. Bajerowej (1996). Zob. także: Kamińska-Szmaj (2014, 2015, 2017); Mazur (2011); Poprawa (2016 a, b, 2017). 
W artykule opisuję więc, w jaki sposób obrazowano rzeczywistość totalitarną w okresie okupacji na terenie tzw. Generalnego Gubernatorstwa, czyli w części przedwojennego państwa polskiego podporządkowanej władzy hitlerowskiej (Trzeciej Rzeszy). Materiałem badawczym są teksty propagandowe autorstwa zróżnicowanych pod względem ideologicznym polskich ugrupowań politycznych, a ich realizacją — prasa konspiracyjna (podziemna), stanowiąca w realiach wojennych przestrzeń komunikacji politycznej (dyskursu politycznego) ${ }^{3}$.

Materiał badawczy odzwierciedla najważniejsze kategorie polskiego dyskursu politycznego, które zderzały się z totalitarnym dyskursem okupanta, czyli wielogłosowy punkt widzenia, zróżnicowanie programowo-ideologiczne, wielopodmiotowość, a co więcej - zbiór treści propagandowych związanych z charakterystyczną dla czasu wojennego retoryką walki z okupantem i retoryką walki o władzę w powojennej Polsce (por. Wolińska 1996; Kamińska-Szmaj 2014, 2015, 2017; Poprawa 2016a, 2017). Został on wynotowany z gazet reprezentujących główne struktury polityczne Państwa Podziemnego (zob. Ignatowicz 2011; Korboński 2008; Bartoszewski 1987), a także ugrupowań pozostających poza głównym nurtem konspiracyjnym, czyli z wydawnictw pod patronatem lewicy radykalnej/komunistycznej (reprezentowanej od 1942 roku przez PPR) i nurtu skrajnie nacjonalistycznego (oenerowskiego) ${ }^{4}$.

\section{1. Źródła leksykalne nazwy totalitaryzm - kilka uwag}

Rzeczownik totalitaryzm - wraz z pokrewnym przymiotnikiem totalitarny ${ }^{5}$ — pojawił się $\mathrm{w}$ polszczyźnie $\mathrm{w}$ tej rozbudowanej wersji strukturalnej dopiero w okresie powojennym ${ }^{6}$. Używany był przed wojną, a także w polszczyźnie lat wojny i okupacji (głównie w dyskursie naukowym, a wtórnie w publicystycznym), ale

${ }^{3}$ Dzieje prasy konspiracyjnej, jej polityczno-ideologiczne zróżnicowanie opisano głównie w pracach: S. Lewandowskiej (1992), J. Jarowieckiego (1980a, b), E. Cytowskiej (1986), B. Golki (1975), W. Bartoszewskiego (1987). Stamtąd też pochodzą najważniejsze informacje i typologia polityczna wydawnictw podziemnych.

${ }^{4}$ Dla porządku są to następujące grupy czasopism: 1) oficjalne organy Delegatury Rządu na Kraj — tygodniki „Rzeczpospolita Polska” i „Biuletyn Informacyjny” ZWZ/AK; 2) wydawnictwa lewicy socjalistycznej (PPS i PPS WRN) - „Robotnik”, „Miasto i Wieś”, „Kurier”, „Gwardia Ludowa”; 3) prasa pepeerowska: „Trybuna Wolności”, „Głos Warszawy”; 4) sanacyjna, związana z przedwojennym Ozonem — „Polska Walczy”; 5) endecka „Walka”; 6) oenerowski (skrajnie nacjonalistyczny) „Szaniec” i „Głos Polski — Pobudka”. Pomijam w tym tekście ich dokładną charakterystykę ideową, zarysowując jedynie konieczny dla analiz lingwistycznych kontekst.

5 Można przyjąć motywację wzajemną tych leksemów, choć według WSJP PAN rzeczownik jest wtórny wobec przymiotnika.

${ }^{6}$ Wersję strukturalnie uboższą jako jedyny wariant notuje również Stownik języka polskiego pod red. W. Doroszewskiego (1958-1969). 
zwykle w wersji uproszczonej totalizm, zapożyczonej z języka francuskiego ${ }^{7}$. Podobnie w uzusie stosowane są dwa warianty przymiotnikowe: totalny i totalistycz$n y$, przy czym ten drugi, już w konkretnym odniesieniu do zjawisk politycznych, pojawia się z wyższą frekwencją dopiero w polszczyźnie lat 1939-1945 (przynajmniej takie poświadczenia ujawnia zebrany do analizy materiał źródłowy) ${ }^{8}$.

Totalitaryzm jest internacjonalizmem, który sytuuje się w polu leksykalnym oznaczającym zjawiska polityczne, a ściśle mówiąc: nazwy koncepcji ustrojowych, sposobów sprawowania władzy (por. Karamańska 2007). W tym też zakresie denotacyjnym pojawia się $\mathrm{w}$ wielu językach $\mathrm{w}$ okresie przedwojennym i wojennym. Skrócona wersja wyrazu odnotowana została w polszczyźnie w latach 30. $\mathrm{XX}$ wieku — obok innych nazw systemów totalitarnych i utożsamianych z nimi prądów ideologicznych. W tym czasie język polityki i prasy gromadzi między innymi takie ,-izmy”, jak: faszyzm, hitleryzm, narodowy socjalizm, bolszewizm, sowietyzm, leninizm (zob. także Kamińska-Szmaj 1994, 2006, 2007). Słownictwo to analizuje bardzo szeroko Marta Karamańska (2007: 51-83) na materiale prasy polskiej lat 1926-1939, wydawanej wówczas, gdy w Europie pojawiają się koncepcje władzy dyktatorskiej (por. Besier 2010; Kershaw 2016), a przede wszystkim wyłaniają się cechy przywództwa totalitarnego i systemy państwowe o cechach hegemonicznych. Po pierwsze, w faszystowskich Włoszech umacnia się na dobre dyktatura B. Mussoliniego, po drugie, w 1933 roku powstaje Trzecia Rzesza, a władzę kanclerską w Niemczech zawłaszcza A. Hitler i podporządkowana mu NSDAP (rozpoczyna się reżim hitlerowski). Ponadto w 1924 roku w Związku

7 Od franc. total 'cały', wywodzącej się z łaciny.

8 Termin totalitaryzm według Wielkiego słownika języka polskiego IJP PAN pod red. P. Żmigrodzkiego ma następujące odpowiedniki w innych językach: ang. totalitarianism, fr. totalitarisme, niem. Totalitarismus. Jest to wyraz motywowany od przymiotnika totalitarny (ang. totalitarian, fr. totalitaire, niem. totalitär), w którym ukrywa się łaciński rdzeń. WSJP wskazuje taką współczesną definicję: »forma rządów, w której władzę sprawuje jedna partia, obowiązuje jedna ideologia, a państwo kontroluje życie obywateli i zwalcza opór i niezadowolenie, stosując przemoc«. Jak podają inne słowniki, pol. totalitaryzm (niem. Totalitarismus < totalitär) został zapożyczony z franc. totalitaire < totalité. Słowo to zawiera w sobie łaciński rdzeń tot/us 'cały, wszystek' rozszerzony w łacinie późnośredniowiecznej do postaci totalis, która ufundowała przymiotnik total 'całkowity, zupełny' (zob. Stownik wyrazów obcych PWN, red. E. Sobol, 2002, oraz Stownik wyrazów obcych W. Kopalińskiego, 1990). Według W. Kopalińskiego użycia polskiej wersji leksemów totalizm i totalny — jeszcze bez obciążających konotacji politycznych — ujawniają się około 1930 roku jako zapożyczenie z francuszczyzny. Nie notuje tych leksemów tzw. słownik warszawski pod red. J. Karłowicza, A. Kryńskiego i W. Niedźwiedzkiego (1900-1927). Natomiast w tym słowniku pojawiają się dwa odprzymiotnikowe derywaty utworzone od podstawy totalny > rzeczownik totalność 'całość, ogół' (np. totalność wojska) oraz totalizować 'łączyć w całość, scalać'. W wydanym w 1939 roku Podręcznym słowniku języka polskiego M. Arcta pojawia się hasło totalizm już w znaczeniu odnoszącym się do świata polityki w sensie ogólnym: »system rządzenia państwa zmierzający do rozciągnięcia kontroli nad całym życiem politycznym, społecznym i kulturalnym«. Według tego słownika totalizm jest substytutem synonimicznym nazwy faszyzm, zestawianym ze »skrajnie nacjonalistycznym i imperialistycznym kierunkiem w polityce, zwalczającym socjalizm i komunizm«. Warto dodać, że według redaktorów WSJP IJP PAN słowo hitleryzm pojawiło się już w 1936 roku. 
Radzieckim/Sowieckim ${ }^{9}$ kierownictwo nad WKP(b) przejmuje J. Stalin, a jego brutalne rządy zostaną nazwane stalinizacją kraju. Zmiany te — jak wynika z monografii krakowskiej badaczki - odbijają się w języku publicystyki politycznej, następują przesunięcia semantyczne dotyczące utrwalonych już leksemów nazywających zjawiska polityczne (ideowe), tym samym też pole leksykalne wzbogaca się o nowe jednostki.

M. Karamańska odnotowuje między innymi następujące wyrazy: bolszewizm, faszyzm, hitleryzm, rasizm, sowietyzm, totalitaryzm (totalizm) oraz ich synonimy i derywaty, jednocześnie zwracając uwagę na to, że nazwy te mają charakter internacjonalizmów, czyli zapożyczeń wprowadzonych do obiegu publicznego, medialnego i politycznego na podstawie interferencji związanych z procesami społecznymi w całej Europie. W pracy tej udokumentowane zostały również frazeologizmy zawierające w swym składzie interesującą nas nazwę: totalizm czerwony, totalizm biaty, autarkia - paradoks totalitaryzmu, zwolennicy totalitaryzmu, tęsknota za totalitaryzmem, totalistyczna kultura, zwolennicy totalitaryzmu. Jak zauważa Karamańska, pojawiają się one w języku prasy około 1938 roku. Badaczka jednocześnie dodaje, że „leksemy totalizm i totalitaryzm, podobnie jak faszyzm i hitleryzm, od razu zaczęły pojawiać się w kontekstach powodujących odmienne wartościowanie, odzwierciedlające różnice światopoglądowe użytkowników języka, a przede wszystkim system wartości”, przy czym pejoratywne wartościowanie zjawisk kryjących się za nimi ujawniało się wyłącznie w tekstach nurtu „nieprawicowego” (Karamańska 2007: 75-77) ${ }^{10}$. Spostrzeżenia te podziela również Irena Kamińska-Szmaj (2006: 207), stwierdzając, że pod koniec lat 30. XX wieku leksem bolszewizm nadal pojawia się jako komponent etykietek politycznych, przypisywanych zwolennikom nurtu lewicowego, a dwa kolejne „-izmy” (faszyzm i hitleryzm) podobnie „stały się jednymi z najczęściej używa-

${ }^{9} \mathrm{~W}$ całym przeanalizowanym przeze mnie na potrzeby niniejszego opracowania materiale badawczym oficjalna nazwa Rosji pojawia się w wariantach: Związek Sowiecki, Rosja Sowiecka lub Sowiety, czyli jako przedwojenna kalka z języka rosyjskiego. Tą nazwą posługują się wszystkie ugrupowania polityczne, a także wydawnictwa PPR-u (np. „Trybuna Wolności”, najważniejsze pismo opiniotwórcze). W 1944 roku — zapewne pod wpływem tekstów politycznych przedstawiających obraz koalicji antyhitlerowskiej — do obiegu wchodzi skrótowiec ZSRR (od nazwy: Związek Socjalistycznych Republik Rad). Jak wiadomo, dzieje przymiotnika radziecki w polszczyźnie są powojenne, jak również oficjalna, administracyjna nazwa kraju zawierająca odniesienia do pluralium rzeczownikowego rady (por. Kleszczowa 1996: 221; Ostaszewska 1996: 273-276). Użycie nazwy Sowiet — zamiast etnonimu Rosjanin — i przymiotnika sowiecki zamiast rosyjski może zdradzać nacechowanie konotacyjne i wypełniać składniki stereotypu propagandowego.

${ }^{10}$ Szczegółowe przeobrażenia dotyczące pojęć nazywających i wartościujących kierunki polityczne, prądy społeczne i hasła ideologiczne od końca XIX wieku zostały opisane w ramach międzynarodowego projektu pt. Słownik pojęć politycznych i społecznych krajów Europy Środkowej $i$ Wschodniej pod kierunkiem Stanisława Dubisza, Józefa Porayskiego-Pomsty i Elżbiety Sękowskiej z Uniwersytetu Warszawskiego. O dziejach pojęć nazw odnoszących się do zjawiska totalizmu więcej w tomach: Dubisz, Porayski-Pomsta, Sękowska (red.) (2004, 2007), głównie w zgromadzonych w nich artykułach metodologiczno-leksykograficznych. 
nych w polemikach prasowych wyrazów o zabarwieniu ekspresywnym (dodatnim lub ujemnym) w zależności od opcji politycznej gazety"11.

Co ciekawe, współcześnie używane nazwy dwóch najważniejszych systemów totalitarnych — stalinizm i nazizm — nie pojawiają się ani w polszczyźnie przedwojennej, ani w polszczyźnie czasów wojny i okupacji; wydaje się, że w takim kontekście nie są używane również w szerszym obiegu językowym. Pierwszy derywat, motywowany od nazwiska rosyjskiego dyktatora, w dyskursie politycznym (niekoniecznie polskim) pojawia się po śmierci Stalina, w czasach „odwilży", głównie po to, aby z punktu widzenia krytyka lub obserwatora nazwać reżimowy, hegemoniczny model władzy w ZSRR od lat 30. do lat 50. XX wieku ${ }^{12}$. $\mathrm{Z}$ kolei internacjonalizm nazizm (prawdopodobnie jako pożyczka z niem. Nasismus) ma sprecyzowaną desygnację, ale jako termin polityczny o ustabilizowanym i neutralnym znaczeniu (in. narodowy socjalizm) funkcjonuje dopiero w leksyce powojennej. Wynika to z faktu, że jako nazwa ideologii narodowego socjalizmu stosowany był w oficjalnym dyskursie hitlerowskiej NSDAP, a także w propagandzie politycznej Trzeciej Rzeszy (por. Klemperer 1989; Neumann 2016) ${ }^{13}$.

11 M. Karamańska (2007: 67) odnotowuje terminy sowietyzm i hitleryzm w artykułach prasowych z 1930 roku, a także popularne w publicystyce lat 30. XX wieku metonimiczne określenia typu Hitleria/Bolszewia - substytuty onimiczne zachodniego i wschodniego sąsiada Polski. Bardzo ciekawe przesunięcia semantyczne zostały odnotowane również przez badaczy zajmujących się tematyką „totalizmów” w dwudziestoleciu międzywojennym. Przykładowo nowy system władzy w Rosji - po przejęciu kierownictwa nad WKP(b) przez Stalina — został nazwany w dyskursie naukowym - prawdopodobnie pod wpływem krytycznego studium A. Kiereńskiego — ,faszyzacją bolszewizmu". Szczegółowo zjawisko to omawia A. Hertz w napisanym w 1937 roku studium O władzy Stalina (za wyd.: Hertz 1994: 305). Zob. także Kamińska-Szmaj (2007); Polkowska (2015).

$12 \mathrm{~W}$ polskich słownikach termin stalinizm zapisany został dopiero w Uniwersalnym słowniku języka polskiego pod red. S. Dubisza (2003) jako wyraz specjalistyczny (termin polityczny) w znaczeniu »polit. okres w historii Związku Radzieckiego i większości państw pozostających w strefie jego wpływów politycznych, charakteryzujący się głównie oficjalnym kultem wodza (J. Stalina), kontrolą polityczną aparatu partyjno-państwowego nad życiem społecznym i gospodarką, terrorem policyjnym i izolacją od świata zewnętrznego«. Termin ten trafia do obiegu po słynnym wystąpieniu N. Chruszczowa z 1955 roku, zapowiadającym krytykę stalinizmu i „,czas odwilży” (por. Kamińska-Szmaj 2007, 2017). Niemniej warto zwrócić uwagę na fakt, że leksem ten pojawia się w polszczyźnie jeszcze przed wybuchem drugiej wojny światowej, choć jego użycie jest efemeryczne. Przykładowo w rozprawie A. Trzaski-Chrząszczewskiego pt. Przypływy i odpływy demokracji (wyd. Polityka 1939), poświęconej „rodowodom totalizmów”, ma on takie poświadczenia: „Nie będziemy wrzucać do jednego garnka dyktatur zachodnioeuropejskich wraz z eurazjatycką, która powstała na skutek zastosowania usystematyzowanej doktryny, jaką był socjalizm. Dopiero od niedawna wyłania się tam ustrój pod postacią stalinizmu, który co do swej natury powoli zbliża się do zachodnich hitlerowskich i faszystowskich wzorów. Także jednak pomiędzy zachodnio-europejskimi „totalizmami” zachodzą różnice” (tamże: 104) oraz: „Obecnie w Rosji nie ma już komunizmu, ani bolszewizmu. A co tam jest w takim razie? Stalinizm, jakie to proste? Stalinizm — to znaczy w imię Lenina i Marksa uprawianie polityki odpowiadającej aspiracjom biurokracji i nowej burżuazji” (tamże: 165).

13 Według WSJP PAN w chronologizacji terminu nazizm podaje się pierwsze użycia w 1943 roku, ale dotyczą one głównie wydanego w Londynie pamfletu M. Hemara pt. Adolf Wielki: pamflet 
„Leksykalne dzieje” totalitaryzmu są mniej oczywiste niż historia zjawiska. Pojęcie to od początku uwikłane zostało w różne znaczenia konotacyjne, a szczególnie zawiłe procesy nazwotwórcze, gdyż podporządkowane — jak w wypadku większości pojęć z zakresu polityki — różnym aksjologicznym kontekstom, a szczególnie wtórnym modyfikacjom ideologicznym. W literaturze przedmiotu przyjmuje się, że pojęcie totalitaryzmu zostało spopularyzowane przez Giovanniego Amendolę krytyka doktryny faszystowskiej i dyktatury B. Mussoliniego. Włoski publicysta socjalistyczny w 1923 roku użył sformułowania sisteme totalitario ${ }^{14}$, by określić tworzące się państwo dyktatorskie pod rządami Duce (m.in. za: Pipes 2005; Ryszka 1985; Müller 2016, por. Totalitaryzmy XX wieku 2010 i in.). Niemniej w języku faszystów włoskich termin ten był prymarnie używany w kontekście pozytywnym, a taką jego recepcję łączy się z popularnością w tamtym okresie prac faszystowskiego filozofa Giovanniego Gentile, a szczególnie jego traktatów z roku 1925, wychwalających rewolucyjne zmiany we Włoszech ${ }^{15}$.

Już od początku ideologicznie naznaczony termin — w wersji pozytywnie nacechowanej - trafił również do LTI, czyli dyskursu nazistów (Klemperer 1989), ale prawdopodobnie wyłącznie do pism teoretycznych z zakresu prawa. Na gruncie niemieckim po 1933 roku został spopularyzowany przez Carla Schmitta, autora koncepcji ,państwa totalnego” (niem. total Staat, zob. Klemperer 1989: 40), dającej przyzwolenie na swobodną manipulację prawem konstytucyjnym przez dyktatorską władzę (por. Neumann 2016; Ryszka 1985). Choć termin ten wykorzystywany był jako dogmat ideologii narodowego socjalizmu, prawdopodobnie nie posługiwał się nim w swych przemowach Hitler. W dyskursie narodowych socjalistów przymiotnik z semem 'total' pojawia się, oczywiście, często — jak zaznacza Piotr Kołtunowski (1990) — jako składnik językowy charakterystycznej figury słownej zwanej „wielkim superlatywem” (określenie Klemperera 1989: 121), a więc na poziomie leksyki gloryfikującej postępowanie władzy hitlerowskiej, a przede wszystkim wyrażającej afirmację wojny. To właśnie $\mathrm{w}$ tej odmianie języka totalitarnego doszło do melioryzacji (zob. Dubisz 2007) używanego w całej Europie pojęcia wojny totalnej, mającego znaczenie neutralne lub sytuującego się w sferze antywartości (por. Holzer 2008:

i dygresje. Wyraz ten jest pożyczką z niem. Nazismus, czy kalką niem. Nazi, pol. nacyzm, w SJPD obok wyjściowej nazwy narodowy socjalizm i synonimów hitleryzm i faszyzm. Definiowany przez WSJP następująco: »totalitarny system ideologiczny i polityczny stworzony w Niemczech przez Adolfa Hitlera, będący skrajną postacią faszyzmu i stanowiący w latach 1933-1945 podstawę polityki państwowej Niemiec, cechujący się skrajnym antysemityzmem i zakładający wyższość rasy aryjskiej nad innymi« (za: www.wsjp.pl).

14 W. Kopaliński w Słowniku wydarzeń, pojęć i legend XX wieku (2004: 428) wyjaśnia, że totalitaryzm ma związek z wyrażeniem państwo totalitarne (wł. sisteme totalitario), które zostało zapisane po raz pierwszy we włoskiej ustawie faszystowskiej z 24 grudnia 1925 roku.

15 Szczegółowe uwagi leksykograficzne na temat źródeł nazw faszyzm i faszysta, ich użyć w polszczyźnie, a szczególnie w języku polityki dwudziestolecia znajdują się w monografii I. Kamińskiej-Szmaj (1994). 
105) i w sferze znaczeń synonimicznych propagandy wojennej (Welch 2003; Jarecka 2008) ${ }^{16}$.

Bardzo szczegółową analizę semantyczno-leksykalną nazwy totalitaryzm przedstawia Franciszek Ryszka w rozprawie pt. Państwo stanu wyjątkowego (1985), opisującej reżim hitlerowski (1933-1945). Badacz szczegółowo omawia dzieje pojęcia w filozofii polityki, wykazując, że termin totalitaryzm został przejęty z języka włoskich faszystów, którym ci posługiwali się jako hasłem afirmującym działania i koncepcje polityczne uderzające w ustrój parlamentarny (pluralistyczny), a więc z założenia antydemokratyczne i wzmacniające siłę partii faszystowskiej. Z kolei wybitny badacz historii XX wieku Richard Pipes dodaje, że prawdopodobnie słowa totalitario użył jako neosemantyzmu po raz pierwszy Mussolini przed 1914 rokiem, a więc w okresie o dekadę poprzedzającym powstanie włoskiego faszyzmu, a samo jego znaczenie przedstawił w swych anonimowych (niepodpisanych z imienia i nazwiska) artykułach publicystycznych (zob. Pipes 2005). Według F. Ryszki postać leksykalna totalitario łączy się z terminologią polityczną lansowaną przez G. Gentile, ideologa faszyzmu. Obok tego rzeczownika pojawił się we włoskim języku propagandy również derywat przymiotnikowy totalitarimente ('totalitarny') jako cecha rządów monopartyjnych (Ryszka 1985: 60-61). Zawarty w obu leksemach sem 'całkowitość' miał oznaczać więc ujednolicenie życia politycznego i społecznego (jego monopolizację) kosztem różnorodności, jednostkowości (pluralizmu światopoglądowego). Poświęćmy nieco więcej uwagi temu wykładowi:

Można zatem wyrazić koncept „totalitaryzmu” na płaszczyźnie leksykalnej jako derywat „totalności” i jeśli z nazwy „autorita” w języku włoskim wywodzi się ,autoritario”, od nazwy „totalita” wywodzić się będzie „totalitario”. Będzie to pozytem semantyczny względem konstrukcji derywatu ,frammentario" pochodzącego od „frammento"; totalność jest bowiem opozycją fragmentaryczności (Ryszka 1985: 61) ${ }^{17}$.

16 Prawdopodobnie po raz pierwszy w funkcji hasła propagandowego o znaczeniu pozytywnym wyrażenia tego użył J. Goebbels w przemowie z 1943 roku, bezpośrednio po klęsce stalingradzkiej. Slogan totaler Krieg ('wojna totalna', por. Kołtunowski 1990: 81), nawiązujący do niemieckich wzorców propagandy wojennej z 1917 roku, miał mobilizować do niszczycielskiej wojny za wszelką cenę, zgodnie zresztą z całą koncepcją życia w totalitarnej Trzeciej Rzeszy. W języku nazistów więc słowo totale od początku weszło do semantyki łączącej treści propagandowe z metaforyką militarną. Stało się więc amalgamatem pojęciowym wielu znaczeń określających militarne cele i dyktatorskie, brutalne metody postępowania hitlerowców. W propagandzie nazistowskiej, aby wyostrzać użycie mobilizacyjne sloganu ,wojny totalnej”, sięgano po intertekstualne nawiązania do spopularyzowanego przez Ernesta Jüngera hasła Die totale Mobilmachung ('totalna mobilizacja'), za: Ryszka (1985: 42).

17 Termin totalizm/totalitaryzm w takim aksjologicznym kontekście został przejęty przez narodowych socjalistów. Według R. Pipesa nazwa ideologii nazistowskiej, wzorowanej na włoskim faszyzmie, również została utworzona prawdopodobnie na wzór włoskiego pojęcia un socializmo nazionale. Jak dowodzi badacz, termin narodowy socjalizm pojawia się jako koncept polityczny już 
Podsumowując ten wątek rozważań, dodajmy, że w sensie ogólnym totalitaryzm to nazwa przede wszystkim cech ustrojowo-prawnych władzy hegemonicznej czy reżimowo-dyktatorskiej, a wtórnie odnosi się do kultury politycznej i propagandy politycznej w tych systemach. Na powojenne definicje o charakterze encyklopedycznym wywarły wpływ doświadczenia wojenne. Termin ten wydaje się rozpoznawalny w poszerzonych wersjach znaczeniowych od lat 60 . XX wieku, $\mathrm{w}$ następstwie ujawnienia się w naukowym obiegu różnych koncepcji badań nad totalitaryzmem. Ich zarys przedstawiam poniższej. W tym miejscu warto dopowiedzieć, że bardzo ciekawe uwagi na temat recepcji pojęcia przynosi również kilkunastotomowa Encyclopedia Americana (wyd. z 1966 roku, t. 26, s. 716), w której pod hasłem totalitarianism (zawierającym też uwagi na temat przymiotnika totalitarian) czytamy, że: 1) po raz pierwszy w 1928 roku pojawiło się wyrażenie „totalitarny reżim" (totalitarian regime) - jako określenie o charakterze politycznym, odnoszące się do dyktatorskich metod władzy, i zostało ono odnotowane w suplemencie do oksfordzkiego słownika terminów politycznych i historycznych z 1933 roku; 2) po raz drugi użyto go w komentarzu dziennikarskim w tygodniku „Time” z 1929 roku, w którym publicysta używa neosemantyzmu totalitarian state 'państwo totalitarne', utożsamiając je z ,państwem militarnym”, a przede wszystkim potępiając „zamach na parlamentaryzm”, będący wynikiem polityki faszystowskiej (we Włoszech) i bolszewickiej (po rewolucji 1917 roku w Rosji).

W języku nauki użycie opisywanego przez nas pojęcia wykrystalizowało się dopiero po 1945 roku, ale od samego początku było reglamentowane. Posługiwano się nim w dyskursie anglosaskim dość powszechnie od 1953 roku, gdy po raz pierwszy w Bostonie odbył się międzynarodowy kongres poświęcony roli przywództwa totalitarnego i następstw totalitarnego terroru w czasie drugiej wojny światowej i w świecie powojennym (Jakubowska-Branicka 2013: 71; Bäcker 1992). To wydarzenie wywarło wpływ na późniejszych teoretyków zjawiska. Niemniej ustalenia badawcze na temat totalitaryzmu docierały do krajów bloku wschodniego w wersji okrojonej albo funkcjonowały w drugim obiegu (np. monografia H. Arendt pt. Korzenie totalitaryzmu z 1951 roku miała swoje pierwsze oficjalne polskie wydanie w roku 1993), albo na skutek retoryki „zimnowojennej” nie obejmowały stalinizmu. Pisze o tym wymownie Richard Pipes:

Moskwa wyrzuciła ze słownika myśli ,postępowej” przymiotnik „totalitarny”; do opisu wszystkich ruchów i reżimów antykomunistycznych miał wystarczyć termin „faszystowski”[...]. Stanowisko partii komunistycznej w tej sprawie sformułowano już na początku lat dwudziestych w uchwałach Kominternu. „Faszyzmem” nazywano ustrój Włoch Mussoliniego i hitlerowskich Niemiec. Miał on być produktem „kapitalizmu finansowego" i narzędziem burżuazji. Oficjalna doktryna sowiecka w tym okresie głosiła, że wszystkie kraje „kapita-

w 1914 roku w artykule opublikowanym czasopiśmie „Il Popolo d'Italia”, a napisanym prawdopodobnie przez Mussoliniego (za: Pipes 2005: 268). 
listyczne" muszą przejść przez fazę faszyzmu, nim zatriumfuje w nich komunizm (socjalizm) (Pipes 2005: 259).

Przedwojenny dyskurs naukowy dopiero kreuje encyklopedyczny obraz pojęcia. Podejmowane są badania socjologiczne nad zjawiskiem dyktatur, niektóre z nich, jak pierwsza analiza socjologiczna zjawiska hitleryzmu, przygotowana przez Floriana Znanieckiego i jego ucznia Teodora Abla (Why Hitler Came into Power, za: Hertz 1939/1994: 269; por. Ryszka 1985), trafiają szybko do międzynarodowego obiegu naukowego. W Polsce w latach 30. XX wieku totalizm wchodzi do słownika pojęć politycznych oraz do języka/dyskursu publicznego przede wszystkim na tle doniesień prasowych i publicystyki podejmującej tematykę zmian ustrojowych i polityki imperialistycznej u wschodnich i zachodnich sąsiadów. Nazwa ta nie ma również statusu rozpoznawalnego pojęcia naukowego, raczej funkcjonuje w rejonie słownictwa publicystycznego o niesprecyzowanej polisemii czy synonimii. Obszerniejszą definicję naukową hasła totalizm zawiera wydany w 1939 roku pod red. Z. Łempickiego leksykon encyklopedyczny o profilu specjalistycznym (Świat $i$ Życie. Zarys encyklopedyczny wspótczesnej wiedzy i kultury, Książnica Atlas, Lwów-Warszawa), w którym zwraca się uwagę na takie cechy totalitaryzmu, jak: 1) kształtowanie przez państwo wszystkich aspektów życia publicznego i prywatnego; 2) rządy monopartii - jako zaprzeczenie parlamentaryzmu, wspierane przez rozbudowę aparatu policji; 3) pokrewieństwo z monarchią absolutystyczną (w zakresie kultu władzy) i merkantylistyczną gospodarką (czyli odgórnie sterowaną przez państwo). Ważne natomiast okazuje się odniesienie do „teraźniejszości”, czyli egzemplifikacja znaczenia, odzwierciedlająca desygnację z wyłaniającymi się w latach 30 . XX dyktaturami. Spójrzmy na fragment hasła zawartego w tej encyklopedii:

Przykładem realizacji państwa totalnego w okresie po wielkiej wojnie jest Trzecia Rzesza pod rządami Hitlera, władza pod rządami Mussoliniego i Z.S.R.R. pod rządami Stalina (Świat i Życie, 1939, t. 2: 2179).

$\mathrm{Na}$ zakończenie tej części rozważań dodajmy, że hasła totalizm/totalitaryzm nie zamieszcza „Encyklopedia Gutenberga” (najpopularniejsze wydawnictwo tego typu, redagowane od 1929 roku i aktualizowane do roku 1938 roku) ${ }^{18}$, aczkolwiek w spisach haseł pojawiają się sylwetki A. Hitlera i J. Stalina oraz opisy faszyzmu włoskiego w perspektywie diachronicznej, z których można odczytać takie cechy systemu, jak:

1) rodowód faszystowski i nacjonalistyczny ${ }^{19}$ (narodowo-socjalistyczna partia niemiecka o zabarwieniu skrajnie nacjonalistyczno-faszystowskim [NSDAP] EG, t. VI, s. 184; kierunek imperialistyczny o silnym zabarwieniu nacjonalistycznym i militarystycznym EG, t. V, s. 31);

18 Pełny tytuł brzmi: Wielka ilustrowana encyklopedia powszechna, wydawnictwo „Gutenberga" (wyd. Helge Fergo), t. 1-22 wraz z suplementem, Kraków 1929-1937.

19 Ta cecha, oczywiście, nie odnosi się do systemu stalinowskiego — w źródle tym brak szerszego kontekstu na temat władzy w ZSRR. 
2) zdobywanie władzy siłą i thumienie praw opozycji, konkurencji politycznej, wykorzystywanie metod brutalnej policji politycznej (po śmierci Lenina, 1924, zdobyt w państwie sowieckim jako generalny sekretarz partii dyktatorska niemal władze, stlumit opozycję lewicowa i jej przywódców [Stalin] EG, t. XVI, s. 181; w stosunku do przeciwników stosuje bezwzględne represje [faszyzm włoski], EG, t. V, s. 31);

3) rytualna symbolika, wyrażająca dominującą, jedynie słuszną ideologię w latach 30. XX zdążono odnotować jedynie komentarz dotyczący sfery rytualnej przypisywanej faszyzmowi w jego wersji włoskiej, por: faszyzm ujęty jest w ramy symbolizmu, posiada specjalny strój (czarna koszulę), ukłon (podniesienie ręki), godto (rózgi liktorskie, fasces), EG, t. V, s. 31.

\section{Totalitaryzm jako przedmiot interdyscyplinarnych badań — rekonesans}

Termin totalitaryzm jako nazwa zamkniętego systemu politycznego o cechach pełnej dyktatury i monopolistycznej władzy, zmierzającej do przejęcia kontroli nad wszystkimi dziedzinami życia, pojawia się w obiegu naukowym i publicystycznym dopiero po drugiej wojnie światowej. Cechy tego zjawiska politycznego - w stosunku do definicji przedwojennych, koncentrujących się na aspektach ustrojowo-prawnych i socjotechnicznych — zostały rozszerzone przez komponenty znaczeniowe odnoszące się do skutków rządów totalitarnych, czyli zdobywania władzy poprzez masowy terror i propagandę, wykorzystującą mechanizmy indoktrynacji oraz oddziałującą na odbiorców przede wszystkim za pomocą retoryki nienawiści i kategorii „wroga obiektywnego”20. Pokazano więc, że ideologia — zwykle zapowiadająca rewolucyjny charakter zmian, na przykład w Niemczech odwołująca się do haseł skrajnego nacjonalizmu i koncepcji rasistowskich, a w Związku Radzieckim głosząca rewolucję klasową i koncepcję władzy „w rękach rad" 21 — jest instrumentem wprowadzania reżimu totalitarnego, terror — narzędziem sprawowania kontroli, a propaganda — środkiem indoktrynacji i przywoływania obywateli do posłuszeństwa.

Propaganda totalitarna $\mathrm{z}$ jednej strony kreuje odrealniony wzorzec życia społecznego, z drugiej zaś podburza przeciwko wyimaginowanemu „wrogowi”,

20 Pojęcie wprowadzone do obiegu naukowego przez H. Arendt (2008). Szerzej o tym zjawisku w kontekście studiów nad systemem totalitarnym m.in. w: Olszewski 2010; Ryszka 1985. Analiza zachowań populistycznych, w których posługiwano się figurą wroga, w rozprawie I. Jakubowskiej-Branickiej (2013), poświęconej głównie odczytaniu mowy nienawiści i uprzedzeń na tle klasycznych prac z zakresu psychologii społecznej, antropologii kulturowej, także językoznawczych analiz języka propagandy w wersji totalitarnej. Zob. także Robins, Post (2007); Doliński, Gamian-Wilk (red.) (2014).

${ }^{21}$ Por. Besier (2010); Müller (2016), także analizy porównawcze w: Besier, Stokłosa (2009); Bankowicz (2010); Olszewska-Dyoniziak (1999). 
wyzyskując spiskową teorię świata lub myślenie ksenofobiczne (w Trzeciej Rzeszy oparte głównie na rasistowskim antysemityzmie). System totalitarny steruje wielokierunkowo tą figurą: $\mathrm{z}$ jednej strony, mówiąc o wrogu i strasząc nim, legitymizuje agresję i terror, $z$ drugiej zaś kontroluje zachowania społeczne, to znaczy wywołuje powszechny strach przed wrogiem, mobilizując do zachowań agresywnych i nienawiści wobec ,innego/obcego" (zob. o retoryce wrogości i nienawiści m.in. w: Głowiński 2002, 2007; Karwat 2008, 2014b). To ostatnie zjawisko jako jeden z syndromów władzy totalitarnej — opisała bardzo dokładnie Hannah Arendt w swej monografii pt. Korzenie totalitaryzmu (The Orygins of Totalitarianism, 1951, zob. II wyd. pol. z posłowiem i komentarzem D. Grinberga, 2008).

Kategoria wroga obiektywnego to figura wykorzystywana przez propagandę totalitarną, a ściślej mówiąc na użytek aparatu terroru. Może obejmować każdą grupę osób, która - wedle spiskowych teorii, stereotypów, mitów zawartych w ideologii państwa totalitarnego - jest ,podejrzana” z tego powodu, ,że nią jest" (por. Arendt 2008: 569-588; por. Wojsław 2017: 50):

Kategoria podejrzanego - jak uzasadnia Arendt - obejmuje zatem w warunkach totalitaryzmu całą ludność. Każda myśl, która odbiega od oficjalnie przepisanej i stale zmieniającej się linii, jest już podejrzana, bez względu jakiej dziedziny ludzkiej aktywności dotyczy (Arendt 2008: 605).

Nieodmiennie cechą dystynktywną totalitaryzmu jest to, że komunikowanie publiczne, zmonopolizowane i sterowane przez brutalną władzę, zawiera w sobie wiele strategii opartych na języku agresji, wykluczenia i dehumanizacji. Związki między terrorem i propagandą (Karwat 2014b: 229-250) — jako dwoma podstawowymi narzędziami sprawowania władzy w reżimach totalitarnych — Franciszek Ryszka (1985: 42) wyjaśnia w znaczący sposób: „Terror zmusza do posłuszeństwa i strachu, a propaganda ogłupia".

W powojennych badaniach nad totalitaryzmem uwagę zwrócono przede wszystkim na zależność między zmonopolizowanym aparatem władzy — ideologią - powszechnym terrorem, czyli zjawiskami uznawanymi za metody dochodzenia do władzy reżimowej i kontroli społecznej w tym dyktatorskim modelu państwa. Badacze zajmujący się totalitaryzmem opisali nie tylko cechy ustrojowe tego systemu politycznego, lecz przede wszystkim jego następstwa utożsamiane $\mathrm{z}$ całkowitą degradacją praw i godności człowieka, a przede wszystkim z ludobójstwem ${ }^{22}$, a więc zbiorowym, wojennym doświadczeniem totalitarnego

22 Termin ludobójstwo (zapożyczenie z ang. genocide) jako nazwa masowych zbrodni został po raz pierwszy użyty przez Rafała Lemkina, polskiego prawnika, który wyemigrował do Stanów Zjednoczonych przed wybuchem drugiej wojny światowej. Wyraz ten pojawił się podczas prac nad przygotowaniem aktu oskarżenia dla zbrodniarzy nazistowskich, którzy stanęli przez Międzynarodowym Trybunałem w Norymberdze. Dzieje pojęcia przedstawia m.in. L.M. Nijakowski (2013); pierwsze wzmianki o charakterze naukowym, a nie tylko dokumentacyjnym, w monografii F. Neumanna (2016). 
aparatu przemocy (z funkcjonowaniem tajnej policji i obozów śmierci włącznie). W obiegu naukowym w 1956 roku pojawiła się definicja systemu totalitarnego przedstawiona przez Carla Friedricha i Zbigniewa Brzezińskiego w pracy pt. Totalitarian Dictatorship and Autocracy (za: Gross 2002: 249-250; Olszewska-Dyoniziak 1999; Bäcker 1992; por. także Besier 2010; Totalitaryzmy XX wieku 2010). Ogromny wpływ na badania nad totalitaryzmem i ludobójstwem wywarła również monografia Hannah Arendt (1951/2008), a także rozprawy z zakresu psychologii społecznej, socjologii, których twórcami byli czołowi intelektualiści europejscy — nierzadko naoczni obserwatorzy rodzącego się hitleryzmu ${ }^{23}$.

Obszerną definicję totalitaryzmu, uwzględniającą przytoczone stanowiska badawcze i odwołującą się do interdyscyplinarnej literatury przedmiotu, przedstawia Roman Bäcker, pisząc, że totalitaryzm jest zjawiskiem

1) odmiennym od wszelkich innych niedemokratycznych systemów rządzenia; 2) specyficznym dla $X X$ wieku — nieistniejącym przedtem w skrystalizowanej postaci, występuje on bowiem w rozwiniętych pod względem technologicznym społeczeństwach, w których możliwe jest zastosowanie skutecznych środków kontroli i oddziaływania; 3) polegającym na całkowitej negacji i jednocześnie zmistyfikowaniu wszystkich pojęć używanych wobec i w ramach społeczeństwa obywatelskiego; 4) charakteryzującym się dążeniem do opanowania wszystkich dziedzin życia społecznego i ludzkiego, a w swej dojrzałej postaci nieograniczoną władzą zorganizowanej grupy, legitymizującej się posiadaniem „prawdy”: wyzwolenia ludzkości, rasy itd., oraz biernym przyzwoleniem tłumu (Bäcker 1992: 12).

Literatura przedmiotu podejmująca tematykę totalitaryzmów XX wieku jest przebogata, gdyż ujmuje problem z perspektywy interdyscyplinarnych badań: politologicznych, socjologicznych, psychologicznych, także językoznawczych. Istotne jest również to, że najważniejsze teorie badawcze powstawały w momencie tworzenia się tych systemów politycznych — często jako znak dezaprobaty mechani-

${ }^{23} \mathrm{~W}$ tym miejscu warto przywołać tytuły rozpraw, które zostały ogłoszone drukiem w Stanach Zjednoczonych w okresie drugiej wojny światowej. Chodzi przede wszystkim o takie monografie, jak: 1) Behemot Franza Neumanna (wyd. w 1942 roku w Nowym Jorku) — rozprawa pokazująca funkcjonowanie sytemu hitlerowskiego, w tym mechanizm zawłaszczania całego państwa przez struktury partyjne NSDAP i tajną policję, a także proces ujednolicania życia obywatelskiego, kulturalnego i mediów masowych, zgodnie z rozpowszechnioną w języku nazistowskim zasadą Gleischaltung 'ujednolicania' (por. Ryszka 1985; Klemperer 1989: 42), oraz budowania systemu prawnego ,wbrew prawu” (tzw. państwa stanu wyjątkowego, państwa totalnego, por. także Ryszka: 1985); 2) Ucieczka od wolności Ericha Fromma z 1941 roku, odsłaniająca mechanizmy „osobowości autorytarnej” oraz mobilizujący charakter propagandy totalitarnej w Trzeciej Rzeszy. Szersze omówienie dziejów i dorobku szkół metodologicznych w obrębie politologii, psychologii społecznej, socjologii i teorii komunikacji zajmującej się propagandą o cechach totalitarnych w okresie wyłaniania się tych systemów (od lat 30. XX wieku do końca drugiej wojny światowej) w: Ryszka (1985); Doliński, Gamian-Wilk (2014); Müller (2016); Besier, Stokłosa (2010); tom Totalitaryzmy XX wieku; Jakubowska-Branicka (2013). 
zmów społecznych, które tworzy totalitarna rzeczywistość. Czołówka światowych intelektualistów tłumaczyła te zgadnienia z perspektywy krytyka, jak i uciekiniera z reżimu totalitarnego. Dziś powiedzielibyśmy prawdopodobnie, że ich dokonania naukowe mieściłyby się w perspektywie krytycznej analizy dyskursu (Wodak 2008) i - co ważne - nie jest to implikacja obciążająca obiektywizm tych badań, gdyż, przykładowo, dorobek przedwojennej szkoły frankfurckiej socjologii (na przykład rozprawy Theodora Adorno czy Herberta Marcuse) powstawały między innymi z takiego powodu: miały obnażać zmiany w Niemczech, a więc przekształcenie Republiki Weimarskiej w państwo hitlerowskie, pisane były przede wszystkim ku przestrodze (zob. Besier 2010; Müller 2016). Choć najważniejsze ustalenia i cechy definicyjne pojęcia totalitaryzmu łączy się z refleksją powojenną, warto zwrócić uwagę na to, że już w okresie międzywojennym świat nauki i świat intelektualistów wskazywał „syndromy władzy totalnej”. Obserwowano zawłaszczanie wolności w ZSRR (po rewolucji bolszewickiej i po przejęciu władzy przez J. Stalina w 1924 roku) oraz w Niemczech (przejęcie władzy przez Hiltera i NSDAP oraz powstanie Trzeciej Rzeszy). Co więcej, w 1940 roku Amerykańskie Towarzystwo Filozoficzne uznało totalitaryzm za formę dwudziestowiecznej dyktatury (za: Bäcker 1992: 8).

Nieodmiennie doświadczenia wojny i totalitarnego systemu doprowadziły również do powstania dzieł naukowych i dzieł kultury, w których w paraboliczny lub eseistyczny sposób opisano mechanizmy języka totalitarnego i destrukcyjnej (dystorsyjnej) funkcji języka propagandy. Chodzi, oczywiście, przede wszystkim o przywoływaną wielokrotnie w badaniach nad „nowomową" antyutopijną powieść George'a Orwella pt. Rok 1984 (wyd. ang. z 1948 roku) oraz o przywoływane już w tym artykule eseistyczne analizy filologiczne Victora Klemperera z lat 1933-1945, wydane w zbiorze LTI. Z notatnika filologa (wyd. w 1947 roku w Niemczech) ${ }^{24}$.

Podsumowując ten z konieczności zawężony zarys dziejów nazwy totalitaryzm i recepcji naukowej pojęcia, warto zauważyć, że przed wybuchem drugiej wojny światowej w polskich pracach socjologicznych pojawiły się ważne, aczkolwiek mniej znane w opracowaniach lingwistycznych, analizy języka propagandy wykorzystywanej w ,państwach totalnych” (zob. także Poprawa 2017). Przykładowo Aleksander Hertz w latach 1936-1939 (zob. Hertz 1994) przeprowadził analizę mechanizmów socjotechnicznych, które wykorzystywane były przez „monopartie" i „drużyny wodzowskie” w trzech systemach totalitarnych: faszystowskim, hitlerowskim i stalinowskim (nazywanych przez znamienitego socjologa ,ustrojami wodzowskimi”). Za najważniejsze zjawiska języka propagandy badacz uznaje: militaryzację słownictwa, mityzację wroga, kult charyzmatycznego wodza, a także biurokratyczną stylistykę przekazu. Zamknijmy więc te rozważania teoretyczne kil-

${ }^{24}$ Wśród najnowszych opracowań przeglądowych podejmujących dzieje polskiej refleksji lingwistycznej nad dyskursem totalitarnym warto wymienić: Kamińska-Szmaj (2007, 2013, 2017); Zemszał (2016). Z kolei o cechach „LTI” więcej w pracach lingwistów zajmujących się propagandą totalitarną III Rzeszy (1933-1945) — przeglądy badań m.in. w: Ryszka (1985); Kołtunowski (1990, 1995) i in. Por. także uwagi wstępne w: Poprawa (2017). 
koma uwagami zawartymi w Szkicach o totalitaryzmie autorstwa wybitnego socjologa. Tak oto pisze A. Hertz o najważniejszych — według niego — strategiach w dyskursie propagandowym używanym przez ,władzę totalną”. Są nimi:

1) język wieców propagandowych:

Zwróćmy uwagę na język — jakim posługują się uczestnicy grupy — który w znacznym stopniu dostarcza wzorów i mowie potocznej. Jest to język wojskowy o swoistych cechach stylu wojskowego, a nawet kancelaryjno-wojskowego.Wyraża się on w sformułowaniach haseł, w zwrotach artykułów, odezw i książek. Wyrażenia takie, jak „naprzód do zwycięstwa”, „równajmy szereg”, „maszerować zgodnie”, „śmiałym natarciem zwyciężymy kres” i setki innych, to charakterystyczne stereotypy pochodzenia wojskowego, które z języka partyjnego przeszły do mowy szerszego ogółu [...]. Zwroty te występują najsilniej w ustach przedstawicieli stronnictw zmilitaryzowanych [uwaga ta dotyczy pism Mussoliniego oraz „Mein Kampf” Hitlera - M.P.] i stamtąd rozchodzą się szerzej” (Hertz 1994: 20).

oraz

2) figura wroga:

Stronnictwa, którymi się tu zajmiemy [o faszystach i nazistach - M.P.], wyrażają poglądy krańcowo nacjonalistyczne. Mityzacja wroga ma dla nich ogromne znaczenie jako czynnik podtrzymywania spójności organizacyjnej, bojowości grupy i tym samym jako ważny środek osiągania celów wychowawczych. Stereotyp Żyda, masona, Abisyńczyka, reakcjonisty, marksisty itp. są tu po prostu niezbędne i zgoła drugorzędne znaczenie ma, jaki przedmiot czy jakie pojęcie poddane zostało mityzacji jako „wróg” [...]. Czy jednak fakt takiej mityzacji wrogów ma decydujące znaczenie dla postępów militaryzacji stronnictwa? Bezsprzecznie nie ma znaczenia, kto został uznany za wroga, do kogo odniósł się proces mityzacji. Ale sama mityzacja świadczy o czymś [...] Żyd, mason czy reakcjonista stają się wtedy symbolami, za którymi kryje się jakaś siła wroga, zagrażająca grupie, i z którą trzeba walczyć. I militaryzacja, która trwa nadal po osiągnięciu przez grupę celu politycznego zdobyciu władzy świadczy, że stan wojny się nie skończył" (Hertz 1994: 58).

\section{Totalitaryzm — przemiany semantyczne nazwy w języku propagandy politycznej okresu drugiej wojny światowej}

Materiał badawczy pokazuje, że nazwa totalizm (wraz z wyrazami pokrewnymi) dopiero $\mathrm{w}$ okresie wojennym przechodzi proces stabilizacji znaczeniowej 
(Dubisz 2007), a stan końcowy tego procesu czytelny jest dopiero w powojennych użyciach słowa, gdyż w prasie okupacyjnej możemy obserwować przede wszystkim zjawiska poszerzania znaczenia (polisemizacji) oraz poszerzenia treści semu 'cały' (in. proces delokalizacji). Należy zwrócić uwagę również na to, że zwykle pojawia się w użyciu derywat totalny, stanowiący składnik jakościowy lub relacyjny ('cały, silny' lub 'charakterystyczny dla totalizmu') zestawień terminologicznych typu państwo totalne, prawo totalne, system totalny itp. Obok niego pojawia się również wariant z przyrostkiem -istyczny, ale zwykle używany w kontekstach wyrażających negatywną ocenę desygnatów (ideologia, państwo, system, prawo, administracja, rządy + totalistyczny) ze względu na taką właśnie ich cechę. W artykułach prasy konspiracyjnej nie odnaleziono przykładów użycia form totalitaryzm i totalitarny, a więc leksemów/derywatów strukturalnie bardziej rozbudowanych.

Zapoczątkowany $\mathrm{w}$ okresie przedwojennym proces nazwotwórczy o nieustabilizowanej desygnacji i przewadze konotacji emotywno-ocennych właściwie rozpoczyna się w okresie drugiej wojny światowej, by doprowadzić do ukształtowania się po wojnie internacjonalizmu naukowego totalitaryzm. Wynika to z kilku przyczyn. Otóż treść desygnacyjna pojęcia staje się bogatsza w stosunku do znaczeń zawartych w przedwojennym leksemie totalizm - nowym komponentem okazują się odniesienia do przemocy, terroru i brutalnej polityki rządów totalitarnych, zmierzających do dehumanizacji jednostki, a także eksterminacji (ludobójstwa).

Wybuch wojny, jej destrukcyjny charakter, a także rzeczywistość okupacyjna, zmuszająca do podporządkowania się surowym prawom życia codziennego oraz destrukcyjnemu ustawodawstwu, pokazują, że państwa utożsamiane z totalnymi realizują również politykę zaborczą i imperialną. Ponadto rozpoznawalne stają się metody propagandy totalitarnej, zawłaszczającej oficjalny obieg komunikacyjny, kreującej wizję świata na usługach reżimu i posługującej się skrajnie uproszczoną, spiskową wizją świata, opartą na figurze „wroga obiektywnego” (za: Arendt 2008; zob. Głowiński 1996, 2002, 2007).

Polityka okupacyjna, a ściśle mówiąc wariantywna kategoryzacja „wroga zewnętrznego" w podziemnym dyskursie politycznym, powoduje, że desygnacja systemów totalitarnych podporządkowana została profilom ideologicznym (aksjologicznym). Przedstawiciele wszystkich konspiracyjnych nurtów politycznych jednoznacznie z pojęciem wroga-okupanta wiążą całą strukturę wojenno-polityczną Niemiec/Trzeciej Rzeszy, leksem hitleryzm w latach wojennych staje się substytutem synonimicznym faszyzmu i totalizmu, a także pojęciem określającym rzeczywistość powszechnie utożsamianą z totalitarną. Największe zróżnicowanie aksjologiczno-emotywne dotyczy obrazu Rosji (Zwiazku Sowieckiego, Sowietów - tylko takie oficjalne nazwy występują w dyskursie politycznym i potocznym), a ściśle mówiąc nadawania wschodniemu sąsiadowi cech państwa totalitarnego bądź pomijania w opisie takich składników znaczeniowych. Powiązane ze wschodnim sąsiadem kategorie 'wroga-okupanta' czy 'państwa totalnego' wynikają ze zbiorowych przeżyć dotyczących okupacji w latach 1939-1941 na wschodnich terenach Polski, 
jak również ze zmieniającej się przez cały okres wojenny polityki polsko-rosyjskiej. Wojenny obraz Rosji — raz postrzeganej jako drugi okupant, raz jako wróg neutralny ('czyli taki, o którym się mówi, że jest wrogiem, ale zachowuje się wobec niego neutralność polityczną') ${ }^{25}$ — zmienia się w zależności od realiów wojennych, wizji propagandowych, a w dyskursie politycznym motywowany jest przynależnością do określonego nurtu politycznego (por. Bokszański 2001: 111-127; Niewiara 2010). Jeśli zatem Rosji przypisywana jest cecha państwa totalnego, to komponenty znaczeniowe wypełniają się treściami odwołującymi się do bardziej złożonych kontekstów niż w obrazie totalitarnych Niemiec, gdyż: 1) cechy systemu politycznego wschodniego sąsiada zestawiane są z potoczną wiedzą o ideologicznych przeobrażeniach, które dokonały się w tym kraju od 1917 roku (leninizm, komunizm), lub z propagandowym stereotypem bolszewizmu i bolszewika (zob. Kamińska-Szmaj 1994), pełniącego przed wojną funkcję hiperonimu wobec wszystkich innych terminów określających to państwo; 2) totalitarny Związek Radziecki postrzega się poprzez odwołania do znaczeń kulturowo-historycznych dotyczących rozbiorów, zaborów, a niekiedy nawet caratu — jako symbolu despotycznej władzy; 3) cechy totalitarne ZSRR postrzegane są poprzez znaczenia odnoszące się do terroru oraz brutalności, niebezpieczeństwa ze strony tajnej policji (NKWD), a także kultu władzy Stalina (chociaż użycie terminu stalinizm $\mathrm{w}$ wojennym dyskursie politycznym się nie pojawia). Ponieważ główny nurt prasy konspiracyjnej dotyczy okupacji niemieckiej, zawarty $\mathrm{w}$ nim obraz totalitaryzmu profilowany jest przede wszystkim przez zbiorowe doświadczenie zagrożenia, jakie niesie z sobą hitleryzm (por. Poprawa 2016a).

\section{Konceptualizacja totalitaryzmu w polskim dyskursie publicznym lat wojny i okupacji — wybrane zjawiska}

Totalitaryzm jako pojęcie definiowane jest rozmaicie, ale konceptualizacja wywodzi się z doświadczeń wojennych, a przede wszystkim dotyczy hitleryzmu. Nazwa ta w wyniku zbiorowych (pokoleniowych) przeżyć wojennych, a więc spotkania z siłą militarną, terrorem i brutalnością władzy okupanta, poszerza swój składnik definicyjny, gdyż — w stosunku do okresu przed 1939 rokiem — pojawiają się nowe desygnacje zjawisk utożsamianych z totalitarnymi. W polskim dyskursie podziemnym utrwalają się trzy nadrzędne ramy znaczeniowe (sfery konceptualiza-

25 Takie rozmyte hasło pojawiało się wjęzyku prasy podporządkowanej rządowi londyńskiemu, czyli np. w „Biuletynie Informacyjnym” czy w „Rzeczypospolitej Polskiej”. Hasło to pojawia się w okresie stabilizacji stosunków polsko-rosyjskich (1941-1943). Miało wyrażać przekonanie, że Związek Radziecki był przez dwa lata drugim okupantem, ale na skutek całej międzynarodowej polityki alianckiej, zmierzającej do zakończenia wojny i pokonania hitlerowskich Niemiec, należy przyjąć w okupowanej Polsce postawę neutralną wobec wschodniego sąsiada. Użycie hasła „,wroga neutralnego" zapoczątkowała seria artykułów w „BI” po napaści Niemiec na Rosję (22 VI 1941), np. tyt. Wroga neutralność (BI 3 VII 1941). Zob. Poprawa (2017). 
cji): 1. 'TOTALITARYZM to TERROR OKUPACYJNY'; 2. 'TOTALITARYZM to NASTĘPSTWO WOJNY TOTALNEJ'; 3. 'TOTALITARYZM to KONTROLA ŻYCIA OBYWATELI i PROPAGANDA', chociaż często występują w formie amalgamatu pojęciowego. W centrum każdej z nich znajduje się obraz hitleryzmu, czyli modelowej dyktatury totalitarnej, której brutalnych metod doświadczają na co dzień Polacy w okupowanym przez Trzecią Rzeszę kraju. Wydarzenia wojenne, a także świadomość tego, że w latach 1939-1941 Polska podzielona została na dwie strefy okupacyjne, powodują, że centralny obraz hitleryzmu staje się podstawą do porównań z systemem politycznym (i aparatem terroru) wschodniego sąsiada. Warto dodać, że analogie te pojawiają się we wszystkich nurtach politycznych poza publicystyką środowisk konspiracyjnych komunistycznych (pepeerowskich). Najbardziej emotywnie nacechowana figura Rosji jako okupanta i państwa totalitarnego ujawnia się w dyskursach środowisk endeckich i oenerowskich, jest ona znamienna również dla całego ruchu polskiej lewicy socjalistycznej (PPS i PPS WRN) i ruchu ludowego, które przez okres wojenny — podobnie jak pozostałe partie włączone w struktury tzw. Państwa Podziemnego — odcinały się od polityki PPR-u (por. Poprawa 2016a, Kamińska-Szmaj 2017).

Pierwsza rama semantyczna, 'terror jako cecha totalitaryzmu', właściwie stanowi prymarną cechę utożsamianą z reżimem hitlerowskim — dotyczy ona całego dyskursu publicznego (określanego w kategoriach martyrologii i walki; Wolińska 1996), jest najważniejszym składnikiem narracji o wojnie oraz doświadczeniem zbiorowym i pokoleniowym, utrwalonym nie tylko w publicystyce, lecz także w formach diariuszowych czy w dyskursie potocznym (zob. Poprawa $2016 \mathrm{~b}$ oraz artykuł w tym tomie; por. Niewiara 2010). Z narracji o charakterze deskryptywnym, czyli bieżących informacji, a także tekstów publicystycznych, wyłania się rama obrazowa terroru okupacyjnego (hitlerowskiego) o dość powtarzalnych kolokacjach, w których pojawiają się predykaty w formie czasu teraźniejszego habitualnego, podkreślające stałość, powszechność i aktualność zjawiska terroru. Leksem terror ma więc nadzwyczaj bogatą frekwencję i w doniesieniach prasowych układa się w następujący typ połączeń:

$\begin{array}{llll}\begin{array}{l}\text { przydawka } \\ \text { jakościowa }\end{array} & \begin{array}{l}\text { rzeczownik } \\ \text { terror }\end{array} & \begin{array}{l}\text { przydawka } \\ \text { przynależnościowa }\end{array} & \begin{array}{l}\text { predykat } \\ \text { (synonimia czasownika } \\ \text { wyrażającego dynamicznośćl } \\ \text { intensyfikację zdarzenia) }\end{array} \\ \begin{array}{l}\text { nieustanny } \\ \text { krwawy }\end{array} & + \text { terror } & \begin{array}{l}+ \text { hitleryzmu } \\ \text { okupantal-ów }\end{array} & \begin{array}{l}\text { szaleje } \\ \text { wzrasta } \\ \text { nie stabnie }\end{array}\end{array}$

Doświadczenie terroru to $\mathrm{w}$ realiach okupacyjnych często masowa śmierć, najwyższy stopień agresji fizycznej i brutalnych czynów. W tekstach prasowych pisze się o aktach terroru $i$ antypolskiej politycelakcji antypolskiej. Obrazowanie 
wzmacniają liczne semy wyrażające 'rozmiar i masowość' zjawiska, np.: posyłać setkami na stracenie, masowy + terror, wywóz, tapanka. W wielu tekstach pojawiają się ponadto (niekiedy w funkcji hiperboli) ustabilizowane połączenia szeregowe, np.: kontrybucje i kontyngenty, więzienia i obozy (koncentracyjne), tapanki i szubienice. Na poziomie środków stylistycznych obrazowych można wskazać zaś liczne nacechowane pogardliwie metonimie hitlerowskiego aparatu przemocy, wśród których dominują określenia wywodzące się z metaforyki zwierzęcej (np. bestie wciąż łakna krwi, zwierzęce instynkty). Nierzadko układają się one w ustabilizowane domeny metaforyczne: fali (fala terroru nie stabnie), rozlewu krwi (ulice splywaja krwia; naród krwawi; potokami krwi naszych braci przesiąkła już nasza ziemia; bruki Warszawy znów czerwienia się krwia), szaleństwa oprawców (szaleństwo terroru, bestie szaleja), a nade wszystko piekla (istne piekło 'doświadczenie ofiary' - szatański/e + plan, metody, pomysty 'działanie agresora').

Jest to jedynie bardzo uproszczony opis całej metaforyki zawartej w wielu wydawnictwach podziemnych analizowanego okresu. Równie wymownym zjawiskiem leksykalnym okazują się metonimie polowania oprawców na ludzi (polowanie trwa, dzikie polowanie na ludzi/na niewolnika, hyclowski proceder tapania ludzi na roboty; szerza się tapanki, wywieźli już łapacze), za którymi kryją się obrazy zarówno masowych egzekucji, jak i aresztowań. Grozę terroru oddają w tekstach prasowych również metonimie pokazujące naturalistyczny obraz codziennego spotkania ze śmiercią, a szczególny sposób obrazowania zawiera się w leksyce obnażającej „biurokratyczną metodykę” postępowania oprawców (np. pobór kontyngentów ludzkich, cotygodniowy rachunek polskiej krwi, codzienna partia ofiar) i masowość zbrodni (masowe mordy/na + etnonimy: Żydach, Polakach).

Okupację, co nie dziwi, obrazowano w kategoriach martyrologii. Prasa konspiracyjna zawiera doniesienia i raporty o sytuacji w kraju, w oddzielnych rubrykach (zwykle na przedostatnich stronach) informuje o aktach terroru. Opisuje to, co się dzieje w okupowanych miejscowościach, a także przedstawia informacje o tragicznych wydarzeniach w obozach koncentracyjnych czy doniesienia o przypadkach zbrodni masowych (aktów eksterminacji). W tych informacjach właśnie ujawniają się opisane powyżej środki językowe, a szczególnie naturalistyczny język i narracja podkreślająca powtarzalność, habitualność zdarzeń, jak na przykład we fragmencie $\mathrm{z}$ tygodnika pepeesowskiego:

Majdanek swym obszarem przewyższa już obszar Lublina [...]. Komory gazowe pracują dzień i noc („Walka i Wolność”, 10 października 1943).

Niektóre z takich doniesień przybierają formę przypuszczeń (pogtoski, krąża najbardziej pesymistyczne przypuszczenia), jak we fragmencie zawartym w najważniejszym organie prasowym AK, w którym uderza fragment dotyczący likwidacji getta warszawskiego, a jeszcze bardziej rama modalna narracji o tragedii Żydów wywożonych do obozu zagłady w Treblince: 
Kierunek podróży - na wschód. Miejsce poznania wywożonych nie jest znane, pogłoski wskazują na rejon Małkini i Brześcia nad Bugiem. Również nie jest znany los wywożonych — na ten temat krążą najbardziej pesymistyczne przypuszczenia („Biuletyn Informacyjny” ZWZ/AK, 30 lipca 1942).

Choć deskrypcja ta sytuuje się na poziomie modalności epistemicznej, w ten właśnie sposób podkreśla się, że terror (a tym samym Shoah) jest zjawiskiem ponadczasowym, a rama metatekstowa konceptualizuje powszechny strach, czyli przeczucie, że ponad bieżące wydarzenia może się pojawić coś bardziej przerażającego (por. Poprawa 2016b: 361). Wymownie o rozmiarze terroru, a właściwie o zamiarach brutalnej polityki okupacyjnej, pisze między innymi „Biuletyn Informacyjny" ZWZ/AK:

Wróg z bezwzględnym uporem rządzi się zasadą: Polskę trzeba utrzymywać w grozie terroru i wyniszczać ją wszelkimi sposobami. Więc trwa wielki terror niemiecki nad Wisłą bez przerwy już piąty rok („Biuletyn Informacyjny” ZWZ/AK, 9 grudnia 1943).

Obraz terroru - jako podstawowy element doświadczenia wojennego i życia w warunkach totalitarnych - wyłania się również z fragmentu raportu na temat zbrodni hitlerowskich, który został opublikowany w tygodniku „Rzeczpospolita Polska”, czyli w oficjalnym organie prasowym Delegatury Rządu na Kraj:

[...] wegetacja w mrokach bez świtu, niewolnicze milczenie, ogromny i przytłaczający aparat terroru, szpiclostwo i zakłamanie propagandy, sztuka rządzenia państwem zeszła na psy, pałki policyjne, obozy koncentracyjne, krwawe egzekucje, głosy protestu uciszane śmiercią, [przez] obóz i bat (,Rzeczpospolita Polska", 7 lutego 1944).

Doświadczenie 'totalitaryzmu jako następstwa wojny totalnej' opisywane jest w perspektywie rozważań nad wojną rozumianą w kategoriach agresji ze strony wroga, a przede wszystkim postrzeganej jako skutek militarnej potęgi i ideologii państwa hitlerowskiego/totalitarnego. Wojna totalna rozumiana jest jako wydarzenie obejmujące wszystkich (Holzer 2008; Jarecka 2008; Welch 2003), ale jej hasło - spopularyzowane $\mathrm{w}$ znaczeniu pozytywnym $\mathrm{w}$ doktrynie państwa hitlerowskiego $^{26}$ (por. Ryszka 1985; Neumann 2016; Arendt 2008) — jawi się jako kolejny

${ }^{26}$ Powszechnie się przyjmuje, że pojęcie „,wojny totalnej” dotyczy wszystkich środków wykorzystywanych w konfliktach zbrojnych, a przede wszystkim udziału w niej ludności cywilnej. Ta praktyka miała swe zastosowanie podczas pierwszej wojny światowej. Wojna totalna (total war) według hasła zawartego w Encyclopedia Americana (1966, t. 26: 716) przede wszystkim wyróżnia się tym, że: 1) obejmuje pełną mobilizację wszystkich sił politycznych, ekonomicznych i psychologicznych - ukierunkowana jest na wzbudzenie i kształtowanie morale wojennego; 2) dotyczy rozwoju broni masowej przy nadzwyczajnych nakładach finansowych; 3) ważne jest w niej jednocześnie znaczenie tzw. frontu wewnętrznego (czyli zaangażowania cywilów) do udziału w wojnie (poprzez kampanie propagandowe). Szczegółowe dzieje pojęcia w: Fabiszak (2007); Jarecka (2008) oraz Holzer (2008); por. także Poprawa (2017). 
składnik przypisywany systemowi władzy hegemonicznej czy totalitarnej. Spójrzmy na kilka domen konceptualizujących predykację 'WOJNA TOTALNA'. Jest to:

— [efekt rządów dyktatorskich]: „Teraz dowiedzieliśmy się najdobitniej na własnej skórze, co to jest wojna totalna. Zaprodukowały ją nam i całej ludzkości państwa dyktatorskie” („Rzeczpospolita Polska”, 7 lutego 1944);

- [powszechne zlo]: „Wojna totalna powiększyła ogromnie ponury rejestr mocy złych, spuszczonych z łańcucha przez pożogę wojenną” („,Rzeczpospolita Polska", 7 lutego 1944)

- [wojna totalitaryzmu ze światem wolności] $\rightarrow$ [czyli: demokracji z faszyzmem]: „Toczy się wojna dwu światów — postępu i ludzkości ze światem zdziczałego barbarzyństwa i zdziczenia. Demokracja z faszyzmem - święta wojna” („Głos”, 13 czerwca 1944); „Walka ludzi uczciwych z łobuzami. Walka demokracji z Łobuzokracją” („Robotnik w walce” PPS WRN, 15 marca 1941).

Wojna i totalitaryzm to również codzienne doświadczenie przemocy — zarówno fizycznej, jak i psychicznej. Państwo totalitarne posługuje się metodami agresji psychicznej jako narzędziem kontroli i zniewolenia, a także metodami indoktrynacji lub socjotechniki, negatywnie oddziałującymi na nastroje osób, przeciwko którym terror i metody wojenne są wymierzone (por. Karwat 2014b). Ważnym więc doświadczeniem jest identyfikacja systemu totalitarnego $\mathrm{z}$ propagandą ${ }^{27}$. O jej sile, a właściwie o propagandzie jako atrybucie totalitaryzmu i socjotechniki wojennej, wypowiadają się wszyscy publicyści prasy podziemnej. Z wielu tekstów wyłania się amalgamat 'wojna - terror - propaganda jako broń', np.:

Społeczeństwo nasze zostało jednak przez propagandę niemiecką opanowane [...]. Tej akcji wroga musimy przeciwdziałać i to przeciwdziałać w sposób stanowczy i zdecydowany („Wolność WRN, 9 lipca 1943);

Moralne jady musiały zatruć wszystko to, co w społeczeństwie polskim

jest słabe moralnie i podatne na totalizm („Biuletyn Informacyjny” ZWZ/ AK, 29 czerwca 1944).

Od samego początku okupacji wydawnictwa podziemne występowały przeciwko propagandzie niemieckiej, szczególnie jej wersji zawartej w tzw. prasie gadzinowej (zob. Poprawa 2017; Cytowska 1986; Głowiński 2000), pisząc między innymi, jak w „Rzeczypospolitej Polskiej” z 25 kwietnia 1941 roku, że:

„Nowy Kurier Warszawski” [tytuł jednego z najważniejszych organów prasowych podporządkowanych całkowicie niemieckiemu urzędowi propagandy w GG - M.P.] i inne gazety w języku polskim ukazujące się obecnie w kraju to niemiecka prasa gadzinowa. Zadaniem jej jest okłamywanie i bałamucenie opinii polskiego społeczeństwa.

27 O triadzie 'tototalitaryzm — przemoc/terror — propaganda', wywodzącej się z pracy H. Arendt (2008), także w monografii M. Karwata (2014b). 
Definiuje się więc system hitlerowski poprzez propagandę na jego usługach, a przede wszystkim poprzez system konotacji dotyczących treści, rozpoznawalnych motywów propagandowych i czołowych postaci utożsamianych ze zmonopolizowanym systemem komunikacji w Trzeciej Rzeszy. Spójrzmy na kilka najważniejszych sposobów obrazowania zjawiska - są nimi np.:

— predykacje typu 'hitleryzm to propaganda': „Dźwignią hitleryzmu od najwcześniejszych początków była monstrualnie rozbudowana propaganda" („Rzeczpospolita Polska”, 28 maja 1944);

— liczne epitety czy synekdochy typu: ,propaganda z tubą Goebbelsa” („,Robotnik", 21 października 1940);

- aluzje, obnażające poziom gazet i reglamentowany w nich zasób treści:

„U Hitlera wszystkie gazety piszą to samo i tylko to, co każe Gestapo” („,Robotnik", 21 października 1940).

Prasa konspiracyjna wszystkich nurtów, dostrzegając „wszechmoc propagandową,"28, jednocześnieprowadzi akcję,,kontrpropagandy”"(zob. Poprawa2017). Każde niemalże wydanie gazety konspiracyjnej — poza informacjami na temat terroru - zawiera również wielogłosowe komentarze na temat tego, co przynoszą niemieckie wydawnictwa oficjalne. Zwykle deprecjonuje się je, a nawet określa w sposób ironiczny czy humorystyczny. Obiektem szyderstwa są przede wszystkim główne postaci reżimu hitlerowskiego (i ich publiczne wystąpienia), jak na przykład w „Robotniku” z 21 października 1940 roku:

Szkoda, że Hitler nie gadał po polsku i u nas w Warszawie. Pewnie by mu jakiś nasz Walek czy Józek z kąta przygadał: „Panie bronet! Nie bądź pan taki cwany! Bujać to my, a nie nas!"”.

Propaganda niemiecka postrzegana jest nie tylko jako system komunikacji właściwy państwu totalitarnemu, lecz także jako odmiana socjotechniki przeznaczonej na użytek wojny. W okresie okupacji pole semantyczne zjawisk dotyczących propagandy poszerza się o metonimię 'propaganda jako broń', a właściwie w tym czasie aktualizują się znaczenia zawarte we frazeologizmach typu wojna nerwów, bitwa nerwów, wojna o mocne nerwy, broń propagandowa. Wymownie oddaje to zjawisko fragment artykułu pt. Propaganda jako broń wojny, zawarty w wydaniu „Biuletynu Informacyjnego” z 26 listopada 1942 roku: „Że umiejętnie prowadzona propaganda może być takim samym narzędziem wojny, jak lotnictwo czy artyleria - dowodzi następujące oświadczenie Churchilla w Izbie Gmin". Tym samym specjalne komórki propagandowe organizacji Państwa Podziemnego, postrzegając propagandę jako broń, wzywają do bojkotu gazet niemieckich, ale także do czujności (por. Poprawa 2017).

28 Jest to termin S. Tchakotine'a z 1939 roku, w tak metaforyczny sposób określający monopolistyczny, jednokierunkowy model komunikacji masowej — zob. Pisarek (2008). O związkach tego terminu w propagandą goebbelsowską piszą m.in. Arendt (2008) i Neumann (2016). 
Wydaje się, że takie właśnie zbiorowe doświadczenie oddziaływania propagandy — w jej wersji zarówno totalitarnej, jak i wojennej — spowodowało, że nastąpiło przesunięcie tego neutralnego przed wojną terminu (używanego też w oficjalnym nazewnictwie instytucji państwa podziemnego, jak np. Biuro Informacji $i$ Propagandy $A K$ ) w kierunku pojęć sytuujących się na pograniczu kłamstwa, manipulacji czy nieuczciwych metod oddziaływania na zbiorowość. W czasie drugiej wojny światowej bowiem dawniejsze, dychotomiczne klasyfikacje metod i środków propagandowych na: „etyczne i nieetyczne, białe i czarne”, „szerzenie wiadomości i stwarzanie wiadomości”, rozróżnienia na „propagandę państw demokratycznych i państw totalnych”, „propagandę pokojową i wojenną” - te wynotowałem z popularnej w podziemnym dyskursie broszury A.T. Lutosławskiego pt. O propagandzie (Londyn 1942) — zacierają się na tle „dobitnych przykładów stosowania kłamliwych wiadomości w celach propagandowych" (Lutosławski 1942: 28). Spotkanie z totalitaryzmem spowodowało, że bezpośrednio po wojnie w wielu językach nazwa propaganda - jako prymarnie nienacechowany termin - stała się etykietką komunikacji reglamentowanej, monologowej, o cechach manipulacji i agitacji (por. Kamińska-Szmaj 2004; Dobek-Ostrowska, Ociepka, Fras 1999). Jak ujmuje to znacząco David Welch, opisujący „dzieje propagandy na użytek wojny totalnej”, w latach 1939-1945 „dwa światy totalitaryzmu dały całemu światu lekcję w ramach ogólnej »rewolucji komunikacyjnej«" (Welch 2003: XVIII — thum. własne).

Prasa konspiracyjna rozbudowuje przede wszystkim obraz hitleryzmu jako tyranii, przenosząc te składniki na językowy obraz wydarzeń wojennych i rozważań politycznych. Z publicystyki wyłaniają się różne profile totalitaryzmu: rządów okupacyjnych, aparatu terroru (np. Gestapo), propagandy i agresji militarnej. Wróg - okupant - ujmowany jest jako modelowe państwo totalitarne, zagrażające pokojowi na całym świecie. Wojna sprawiła bowiem, że dawne wyobrażenia o totalitaryzmie nabierają rzeczywistego znaczenia. Totalitaryzm - w świetle artykułów publicystycznych - to przede wszystkim:

- [synonim państwa okupującego - antonim wolności, pokoju i demokracji]: „Nasza walka o wyzwolenie jest odcinkiem w wielkim froncie demokracji świata walczącym z totalizmem” („,Robotnik w walce”, 14 stycznia 1941);

— [synonim dyktatury — antonim demokracji] ,[Dyktatury, które M.P.] opanowały władzę w wielu krajach, podeptały wolność człowieka, sponiewierały swobody obywatelskie, wprowadziły panowanie despotyzmu, tyranii i okrucieństwa” („Rzeczpospolita Polska”, 7 lutego 1940), „Pragniemy demokracji, a nie brunatnej, czarnej czy czerwonej dyktatury” („Biuletyn Informacyjny” ZWZ/AK, 27 października 1943); „Lud pracujący całego świata musi w walce z tyranią i zaborczością totalistycznych dyktatorów zjednoczyć się pod hasłem: Za Waszą Wolność i Naszą!” („Robotnik w walce” PPS WRN, 15 marca 1941). 
Jest to ustrój polityczny o cechach dyktatury, despotyzmu i tyranii, utożsamiany nie tylko z konkretną ideologią, lecz przede wszystkim z utratą wolności przez obywateli (ucisk, niewolnictwo, nietolerancja) w sensie ogólnym:

— [inaczej też system niewolniczy]: „Państwo zostało przemianowane na złowrogie i okrutne bóstwo, które obywateli swoich zmienia w niewolników” (,Rzeczpospolita Polska”, 7 lutego 1944); „Duch ucisku i nietolerancji rozpanoszył się na wielkich przestrzeniach ziemi” („Rzeczpospolita Polska”, 7 lutego 1944); „Nowa forma niewolnictwa w totalnym systemie” (,Biuletyn Informacyjny” ZWZ/AK, 2 września 1943); ,[Faszyzm - M.P.] wychował naród w sposób gruntowny: rycyną, kijem i szubienicą” („Robotnik WRN”, 4 czerwca 1944).

Za najważniejszą cechę dyktatury - prymarnie utożsamianej z hitleryzmem i faszyzmem, a sekundarnie ze stalinizmem (ale tylko przez ugrupowania „niepepeerowskie") - uznaje się całkowitą ingerencję państwa w życie obywateli, ideologiczną indoktrynację, a właściwie utratę swobód obywatelskich przez jednostkę, a przez to całkowitą kontrolę życia społecznego i jego ujednolicenie:

— [kontrola życia ludzkiego i brak swobód dla jednostki]: „I niemiecka, i moskiewska ideologia starają się [...] zetrzeć na miazgę jednostkę” („Polska Walczy”, 28 listopada 1940); "Człowiek w ustrojach totalistycznych stał się pozbawioną indywidualnych cech cząstką ujętej w karby terroru masy ludzkiej" („Polska Walczy”, 1 października 1940).

Dogmaty prawne, a także organizacja ustroju totalitarnego, opierają się na hegemonicznej władzy oraz na kulturze politycznej poddaństwa (por. Kamińska-Szmaj 2007), a system sprawowania rządów - według publicystyki konspiracyjnej - sprowadza się do dwóch najważniejszych cech: kultu wodza i władzy ustawodawczej, wykonawczej i sądowniczej w rękach monopolistycznej partii ${ }^{29}$ :

- [jest to inaczej zasada wodzostwa i monopolistycznej partii na usługach dyktatora]: „Ani w Rosji, ani w Niemczech, ani we Włoszech nie chodzi o żadne idee i przebudowy świata, tylko o niczym nie ograniczoną władzę jednostki, przy której żeruje oddana jej banda” („Robotnik” PPS, 21 grudnia 1940).

Poza terrorem, który w teorii państw totalitarnych jest metodą kontroli życia społecznego, a także całkowitego przejmowania władzy, zastraszania opozycji i zniewalania tych, którzy w duchu ideologii nie należą do „wspólnoty” lub są uznani w niej za wrogów, wojna ujawnia jeszcze jedną cechę systemów totalitarnych: tendencje militarystyczne lub imperialistyczne. Spotkanie właśnie z tymi właściwościami reżimów okupacyjnych - w perspektywie polskiej polityki i konfliktu militarnego - okazuje się równie ważnym elementem znaczeniotwórczym. Wojna w obrazie świata zawartym w prasie konspiracyjnej to bowiem narzędzie przejmowania władzy w Polsce lub pozbawiania Polski państwowości.

29 Następuje więc refleksyjna i krytyczna konceptualizacja używanego również w publicystyce opisywanego okresu pojęcia Führerprinzip, por. Neumann (2016); Ryszka (1985), także przedwojenne studia Hertza (1994). 
Dlatego też okupant (w zależności od linii politycznej ugrupowań: dwaj okupanci) to nie tylko „wróg wojenny”, ten, z którym się walczy, ale przede wszystkim państwo zaborcze, imperialistyczne, natomiast dokonana przez niego agresja i narzucona okupacja to bagatelizowane przed 1939 rokiem prawdziwe, niezamaskowane oblicze totalizmów:

W roku 1939 totalizm uderzył z niepowstrzymaną furią. [...] Ukazało się prawdziwe, niezamaskowane oblicze totalizmów, hasła przemocy i panowania zaborczych imperializmów, hasła najbardziej agresywnych imperializmów” („Polska Walczy”, 1 października 1940); „Okupacja rosyjska w Polsce niewiele się różni od niemieckiej [...]. Dla nas dziś Rosja Stalinowska to wróg taki sam, jak sprzymierzone z hitlerowskie Niemcy! (,Robotnik w walce" PPS WRN, 21 grudnia 1940).

Aby wyostrzyć obraz systemów totalitarnych, bardzo często w gazetach konspiracyjnych wprowadza się porównania i analogie między reżimami. Z jednej strony mają one pokazać cechy wspólne, niejako zaktualizować na tle rozważań o współczesności dawniejsze, przedwojenne konceptualizacje, z drugiej zaś w wielu artykułach zawarta jest implikacja, że okupacja hitlerowska się kończy, ale może się pojawić kolejna, gdyż w perspektywie konfliktu polsko-rosyjskiego (zerwanie układów dyplomatycznych w kwietniu 1943 roku), po pokonaniu wojsk niemieckich przez Armię Czerwoną i w związku z coraz aktywniejszą działalnością PPR-u następuje przejmowanie władzy w Polsce przez komunistów. Tym samym dość często pojawiają się analogie zawierające supozycję: ,'komunizm to stalinizm i hitleryzm/faszyzm - to dwa podobne porządki totalitarne', np.

Świat hitlerowski, komunizm rosyjski i faszyzm włoski wyrastają z jednego pnia i pomimo jaskrawych odrębności wyrażają jedną i tę samą zasadę („Polska Walczy”, 1 sierpnia 1940); „Między narodowym socjalizmem Hitlera a komunizmem Stalina, między ustrojami [...] obu dyktatorów — różnic istotnych nie ma [...]. Dowody braku różnic między totalizmem wschodu i zachodu można mnożyć bez końca („Robotnik”, 1 kwietnia 1941).

Owe implikacje - jak w przywołanych fragmentach — pojawiają się w prasie, która relacjonuje to, co się dzieje za wschodnią granicą (jeszcze w okresie okupacji wschodnich terenów przez ZSRR). W okresie późniejszym mają one wzniecać zbiorowe nastroje, gdyż przybierają postać przestrogi przed narzuceniem władzy przez Związek Radziecki - postrzegany jako państwo totalitarne, tylko z inną ideologią i innym kultem wodza niż w Trzeciej Rzeszy. Taka rama ujawnia się w wielu apredykatywnych sloganach zawartych $\mathrm{w}$ artykułach antykomunistycznych, pisanych również $\mathrm{w}$ prasie ludowców, np.: „Brunatny hitleryzm - czerwony stalinizm” (tytuł art., „Głos Ludu”, 1 grudnia 1943). Czołowe hasła antykomunistyczne mają charakter mobilizacyjny, jak np. w pepeesowskiej „Gwardii Ludowej”: „Oto naród polski z tą samą pogardą, z jaką odtrąbił od siebie agentów 
totalizmu hitlerowsko-faszystowskiego, z taką samą pogardą odwraca się od totalizmu komunistycznego” („Gwardia Ludowa” PPS WRN, 1 stycznia 1944).

Przedstawiony powyżej fragment aktualizuje wiele znaczeń konotacyjnych, gdyż prawdopodobnie dotyczy powołania w Warszawie Krajowej Rady Narodowej (1944), czyli organu ustawodawczego PPR-u pod zwierzchnictwem Bolesława Bieruta. Gazeta lewicowa zatem krytycznie, choć implicytnie, pisze o przejmowaniu władzy w Polsce przez komunistów, a tym samym uznaje za legalną władzę wyłącznie rząd emigracyjny (londyński) i stojącego na jego czele od 1943 roku premiera Stanisława Mikołajczyka, przywódcę ludowców (zob. więcej w: Kamińska-Szmaj 2014, 2017).

Propagandowy obraz hitleryzmu i rzeczywiste doświadczenie terroru hitlerowskiego jako narzędzia sprawowania władzy w okupowanej Polsce mają swą „życiową dokumentację" w zbiorowych przeżyciach. Najbardziej wyrazistym tego obrazem są terror i masowe zbrodnie utożsamiane $\mathrm{z}$ właściwościami państwa totalitarnego. Dlatego też brutalny aparat państwa policyjnego — poza ideologią i propagandą - staje się podstawowym wyróżnikiem w procesie nadawania znaczeń nazwie totalizm. Prasa konspiracyjna nie tylko dokumentuje zbrodnie, deprecjonuje tę najważniejszą cechę reżimu, lecz także konceptualizując „,medialny obraz zjawiska" nazwany po wojnie przez Hannah Arendt (1951/2008) oraz Zbigniewa Brzezińskiego i Carla Friedricha (1954), ,syndromem totalitaryzmu”, poszukuje cech wspólnych i cech inwariantnych dla porządków uznawanych za totalitarne. Zawierają się one w poniższych symbolicznych porównaniach, wyrażających nazwy instytucji władzy totalitarnej i sprowadzone do synekdochy nazwy miejsc niewoli i zagłady:

NKWD, czyli pod naszą nazwą, dawna GPU, czyli - jeszcze dawniejsza "Czerezwyczajka" - rodzona siostra dobrze teraz przez nas poznanej niemieckiej Gestapo” („Robotnik” PPS, 21 grudnia 1940); „Czeka i NKWD — Hitlera Gestapo, tam setki tysięcy Polaków mrze w obozach syberyjskich, tu - setki tysięcy ginie w Oświęcimiach i Majdankach. Czerwony Stalinizm — brutalny hitleryzm — to jedno („Głos Ludu” 1 XII 1944).

Prasa konspiracyjna wydawana na terenie Polski okupowanej przez Trzecią Rzeszę rozlicza następstwa totalitarnej polityki hitlerowskiej, przedstawiając $\mathrm{w}$ formie konstatacji i pogłębionej, wieloaspektowej analizy obraz reżimu. Głównie odnosi ten obraz do tragicznych doświadczeń i metod agresji na ziemiach polskich (terroru, brutalnego niszczenia, fali barbarzyństwa, niewoli i zagłady, więzienia hitlerowskiego władztwa itp.), wyróżniając również charakterystyczne cechy militarne i psychologiczne wojny (totalna wojna, totalne, wojny dzisiejsze to wojny totalne) i agresywnej propagandy wojennej (wojna nerwów i propaganda, nowa broń psychologiczna 'propaganda', wiek propagandy). 
Hitleryzm - jako prototypowy model państwa totalitarnego — obrazowany jest przede wszystkim na poziomie języka oddającego doświadczenie okupowanego społeczeństwa. Na podstawie materiału źródłowego udało się zrekonstruować m.in. następujące formy leksykalne, utrwalające językowy obraz tego pojęcia, a przede wszystkim omówione już znaczenia:

Tabela 1. Hitleryzm — obraz pojęcia w słownictwie prasy okupacyjnej

\begin{tabular}{|c|c|}
\hline derywaty & $\begin{array}{l}\text { zhitleryzowanie świata vs. front antyhitlerowski, koalicja } \\
\text { antyhitlerowska } \\
\text { hitlerowsko-faszystowski, hitlero-faszyzm, Hitleria, Hitlerland }\end{array}$ \\
\hline $\begin{array}{l}\text { szeregi — wyrażające } \\
\text { związki/ porównania z innymi } \\
\text { totalizmami }\end{array}$ & faszyzm, hitleryzm czy komunizm \\
\hline kolokacje & $\begin{array}{l}\text { chwyty 'manipulacja', ksiązka 'Mein Kampf', rozkaz, } \\
\text { szatańska zbrodnia + Hitlera; barbarzyńskie hordy Hitlera } \\
\text { kultura/propaganda + hitlerowskich Niemiec }\end{array}$ \\
\hline — w tym frazeologizmy & $\begin{array}{l}\text { faszystowski }+ \text { totalizm, faszystowsko-totalna ideologia, } \\
\text { faszystowskie ktamstwo vs. blok antyfaszystowski } \\
\text { okupant niemiecki, bestia niemiecka, niemieckie manewry } \\
\text { polityczne, terror okupanta } \\
\text { bestia/potega/nawała germańska; jad germańskiej okupacji } \\
\text { brunatna fala, brunatny totalizm }\end{array}$ \\
\hline synonimy & $\begin{array}{l}\text { okupant, wróg } n r 1 \text {, propaganda }+ \text { wroga, władza najeź- } \\
\text { dźcza, dyktatura, rząd okupacyjny }\end{array}$ \\
\hline $\begin{array}{l}\text { pejoratywno-ekspresywne epitety } \\
\text { nt. przedstawicieli wladzy okupa- } \\
\text { cyjnej - zwykle w funkcji inwek- } \\
\text { tywy }\end{array}$ & $\begin{array}{l}\text { pogardliwe: ober-oprawca/ober-kat Frank/Kuczera, pajac } \\
\text { Hitler } \\
\text { ironiczne: uczony Frank, intruz wawelski Frank, mędrcy } \\
\text { hitlerowscy, pan Goebbels, pomystowy Goebbels, naganiacz } \\
\text { wojenny Goebbels, ,sam” Goebbels }\end{array}$ \\
\hline inne połączenia & $\begin{array}{l}\text { Niemcy } i \text { ich satelici, ponury cień Oświęcimialzbrodnie } \\
\text { Majdanka, ,oś”, trójkąt Rzym-Berlin-Tokjo }\end{array}$ \\
\hline
\end{tabular}

Źródło: opracowanie własne.

Natomiast najważniejsze leksemy z rodziny tej nazwy tworzą następujące połączenia, które zestawić można nie tylko na poziomie strukturalnym, lecz także na poziomie wyrazistych cech wchodzących w skład definicji: 

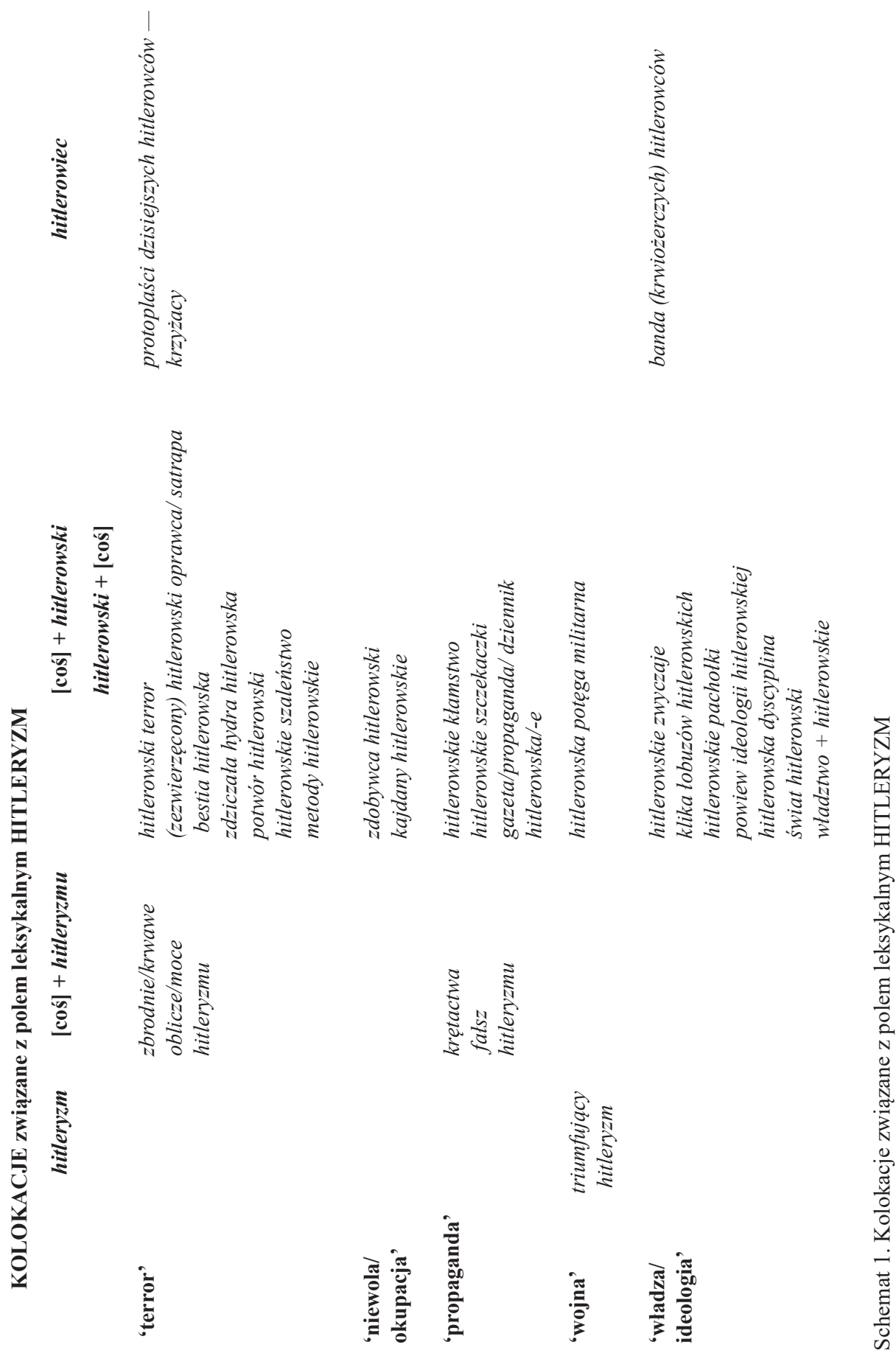
O hitleryzmie pisze się w kategoriach zbiorowego przeżycia, co przekłada się na emotywny, impresywny obraz zjawiska. W polszczyźnie okresu wojennego nie jest to już pojęcie tak rozmyte i niestałe aksjologicznie jak w publicystyce przedwojennej (Kamińska-Szmaj 2007; Karamańska 2007). Nazwa jednoznacznie wchodzi w obszar zjawisk pejoratywnych i w sferę antywartości. Niektóre cechy konotacyjne, powstałe na poziomie dominującej w dyskursie politycznym retoryki walki z wrogiem, oporu i mobilizacji (por. Wolińska 1996), stają się także cechami definicyjnymi prymarnymi. Co więcej, konceptualizacja zjawiska hitleryzmu staje się punktem odniesienia dla całej sfery wyobrażeń utożsamianych z systemem politycznym zamkniętym i kulturą polityczną reżimowo-poddańczą, czyli z totalitaryzmem. Można powiedzieć więc, że właśnie tragiczne doświadczenie hitleryzmu, grozy okupacji i brutalnej polityki Trzeciej Rzeszy rozpoczęło proces nazwotwórczy pojęcia totalitaryzm w polszczyźnie. W obrębie pola semantycznego odnoszącego się do nazwy totalizm następuje scalanie prymarnych cech definicyjnych, wywodzących się ze afery antywartości, a tym samym pojawia się stabilność aksjologiczna pojęcia. Mówiąc inaczej: nazwa ta może być przypisywana różnym reżimom o cechach brutalnej dyktatury, ale tym samym w opisywanym okresie wychodzą z obiegu przedwojenne użycia totalizmu jako słowa klucza pojawiającego się w kontekstach propagandowych chwalących ten model ustrojowy. Hasło polityki totalnej — jak ujawnia to materiał źródłowy — wycofuje się z pojęć normatywnych zawartych w programach ugrupowań politycznych (takie występowały przed 1939 rokiem w nurtach skrajnie nacjonalistycznych, zob. Karamańska 2007; Polkowska 2015). Nie ujawnia się ono również wprost $w$ wojennych tekstach propagandowych ugrupowań, które przed wojną nie ukrywały swego ,zainteresowania” zmianami zachodzącymi w Trzeciej Rzeszy.

O ile podstawowe składniki definicji są czytelne, o tyle w polu leksykalnym zjawisk utożsamianych $\mathrm{z}$ totalitaryzmem pojawiają się inne, wtórne procesy nazwotwórcze czy semantyczne. Leksyka z tego pola wchodzi na obszar etykietki politycznej czy nawet inwektywy, którą posługują się przedstawiciele skłóconych z sobą ugrupowań politycznych, prowadzących walkę nie tylko z okupantem, lecz także z „wrogiem wewnętrznym” (por. Poprawa 2016a). Określenia dotyczące hitleryzmu (ale także stalinizmu) zostają włączone w sieć porównań. Co więcej, na poziomie języka polityki opisywanego okresu tworzą sieć amalgamatów pojęciowych, analogii, znaczeń naddanych, oderwanych od konkretnych desygnatów. Wykorzystywane bywają jako strategia walki z przeciwnikiem politycznym - mają bowiem przenosić konotacje lub implikacje, że jej adresat reprezentuje poglądy wywodzące się $\mathrm{z}$ totalizmu albo postępuje na rzecz krajów totalistycznych, np.: w klimacie ideologii hitlerowskiej, agenci totalizmu hitlerowsko-faszystowskiego, faszyzować (faszyzujacy), mentalność faszystowska, faszysta polski, nasi faszyści spod znaku, próba wprowadzenia totalizmu z całym jego balastem frazeologii. Okazują się szczególnie znaczące, gdy wchodzą w predykacje sugerujące zamiar zdrady, działań na rzecz wroga, jak w przykładach: 
agenci dyktatury + przymiotnik motywowany od nazw systemów uznawanych za totalitarne, walka z (obca) zaborczościa/imperializmem/totalizmami, agentury + hitlerowsko-faszytowskie/komunistyczne, sowieckie, V (piata) kolumna niemiecka/ sowiecka, iść na lep propagandy czerwonej/ hitlerowskiej.

Takimi inwektywami wymieniają się przedstawiciele wszystkich ugrupowań, co też pokazuje, że retoryka walki — zupełnie inaczej zapisana w powojennej pamięci społecznej i zupełnie odmiennie przedstawiana na obszarze polityki historycznej (jako dyskurs martyrologiczny i dyskurs wspólnej walki) - miała dwie twarze: uderzała zarówno w okupanta, jak i w przeciwnika ideowego (politycznego). Oto przykłady kilku bardziej nacechowanych użyć słownictwa negatywnie wartościującego:

Dla faszystów i dla komunistów nie ma w Polsce miejsca. [...] Wszystkie inne doktryny [poza] pniem demokracji będą zwalczane i obracane w niwecz" („Rzeczpospolita Polska”, 7 lutego 1944); „Oto naród polski z tą samą pogardą, z jaką odtrąbił od siebie agentów totalizmu hitlerowsko-faszystowskiego, z taką samą pogardą odwraca się od totalizmu komunistycznego („Gwardia Ludowa", styczeń 1944).

We wszystkich nurtach tego bardzo zróżnicowanego, spolaryzowanego dyskursu politycznego kształtuje się obraz państwa totalitarnego, które sytuuje się na przeciwległym biegunie aksjologiczno-znaczeniowym w stosunku do świata demokracji (dotyczy to szczególnie leksyki konotującej pojęcia wolności i pokoju). Przeciwieństwa totalizmu i hitleryzmu to: blok antyfaszystowski, świat wolny, Alianci, trwaty pokój międzynarodowy, wspólnota wolnych narodów, a wojna z hitleryzmem (czyli $\mathrm{z}$ totalitaryzmem) jest przedstawiana jako wojna o godność człowieka, walka o lepsze jutro ludzkości, także walka w obronie podstawowych dla ładu demokratycznego wartości (jak wolność, jednostka). Wszystkie te użycia odnoszą się do antywojennej polityki aliantów (świętego przymierza/świętej wojny). Przedstawia się ją zaś za pomocą metaforyki wolności, odzyskania niepodległości i klęski militarnej Trzeciej Rzeszy (hitleryzmu), ale także odrodzenia na nowo ładu demokratycznego w Europie. Każde ugrupowanie podziemnej sceny politycznej dostrzega sitelpotęgę Sprzymierzonych (czyli Koalicji Antyhitlerowskiej, także Konstytucji/Karty Atlantyckiej). Przy spolaryzowanych postawach, oczywiście, różnorodna jest desygnacja aliantów. Co ciekawe, z wielu tekstów publicystycznych opublikowanych w 1944 roku wynika, że zaprzeczeniem militaryzmu i totalitaryzmu ma być powojenna wspólnota państw europejskich. W tekstach wojennych ujawnia się niemalże prorocza wizja ładu demokratycznego w Europie, której zwieńczeniem ma być powstanie państw Unii Europejskiej. Gazety konspiracyjne, śledząc wydarzenia międzynarodowej dyplomacji, piszą o idei Stanów Zjednoczonych Unii Europejskiej, które miałyby powstać na wzór Stanów Zjednoczonych Ameryki (pisze o tym często od kwietnia do czerwca 1944 roku zarówno prorządowa „Rzeczpospolita Polska”, jak i pepeerowska „Trybuna Wolności”). 
W całym wojennym dyskursie prasowym leksem totalizm poszerza swoje pejoratywne znaczenia. Mimo tragicznych zbiorowych doświadczeń wojennych w niektórych wydawnictwach można jednak odnaleźć prymarne, przedwojenne znaczenia, zdradzające sympatię publicystów związanych ze skrajnymi nurtami politycznymi dla pryncypiów doktryny faszystowskiej ('siły’ itp.) i zawartej w niej wizji państwa totalnego. Takie implicytne sądy ujawniają się przykładowo w oenerowskim „Szańcu”, który w pozytywnych kontekstach używa określeń typu faszyzm demokratyczny czy demokracja totalna, a nawet posługuje się implikacjami, jak w przykładzie: „Zło nie tkwi w samym faszyzmie, lecz w zbrodniczych skłonnościach duszy niemieckiej” („Szaniec”, 15 lutego 1942).

Materiał językowy wynotowany z prasy konspiracyjnej pokazuje, że w okresie drugiej wojny światowej wyraz totalizm wypełnia się różnymi treściami znaczeniowymi w stosunku do jego użyć i znaczeń przedwojennych. Niemniej — pomijając użycia jednostkowe - sytuuje się w sferze pojęć negatywnych. Substytutami pojęcia stają się określenia i nazwy odnoszące się do hitleryzmu, faszyzmu i narodowego socjalizmu, a w kręgu publicystów negatywnie oceniających politykę ZSRR względem Polski i piszących wprost o okupacji rosyjskiej (1939-1941) — także słownictwo dotyczące porządku politycznego w stalinowskiej Rosji i brutalnego aparatu przemocy pod rządami Stalina. Podsumowując wszystkie analizy, a także uwzględniając reprezentatywne zjawiska zawarte w materiale badawczych (różne punkty widzenia i cechy definicyjne, konotacyjne), można zrekonstruować następujący obraz totalizmu, wyłaniający się z tekstów publicystyki konspiracyjnej i języka polityki tamtych czasów:

Tabela 2. Konteksty znaczeniowe pojęcia totalizm w tekstach publicystyki okupacyjnej

\begin{tabular}{|l|l|}
\hline \multicolumn{2}{|c|}{ Obraz totalizmu w języku polskiej propagandy politycznej okresu } \\
drugiej wojny światowej
\end{tabular}

${ }^{30}$ Użycie niezwykle rzadkie, z późniejszego okresu propagandy wojennej. 


\begin{tabular}{|c|c|}
\hline $\begin{array}{l}\text { 'opartych na zasadzie } \\
\text { wodzostwa i kulcie } \\
\text { jednostki' } \downarrow\end{array}$ & zasada wodzostwa, dziki autorytet władzy \\
\hline $\begin{array}{l}\text { 'prowadzonych } \\
\text { przy wsparciu } \\
\text { monopolistycznej } \\
\text { partii' } \downarrow\end{array}$ & $\begin{array}{l}\text { wódz i jego banda; podzial na rzadzacych i rzadzonych w formie } \\
\text { bezwstydnej i brutalnej }\end{array}$ \\
\hline $\begin{array}{l}\text { ‘odwołujący się do } \\
\text { dominującej ideologii, } \\
\text { zawłaszczającej życie } \\
\text { obywateli, kulturę } \\
\text { itp.’ } \downarrow\end{array}$ & $\begin{array}{l}\text { cechy wyróżniające ideologię (zawarte w niej przekonania i zespoły } \\
\text { sądów): czerwony totalizm; brunatna, czerwona, czarna dyktatura, } \\
\text { imperializm ,,rasy” panującej, instynkty nacjonalistycznel } \\
\text { imperialistyczne } \\
\text { użycie tej ideologii w języku: hasta panowania nad światem, } \\
\text { przemocy i podboju, destrukcyjna siła; szerzy zagładę i zbrodnię, } \\
\text { propaganda totalna }\end{array}$ \\
\hline $\begin{array}{l}\text { 'z tego powodu } \\
\text { odznacza się } \\
\text { ujednoliceniem życia' } \downarrow\end{array}$ & ubrać się w jeden mundur \\
\hline $\begin{array}{l}\text { 'rozumianym jako } \\
\text { kontrola przez } \\
\text { państwo każdej sfery } \\
\text { życia' } \downarrow\end{array}$ & $\begin{array}{l}\text { system policyjno-biurokratyczny; stalowa klatka wspótczesnej } \\
\text { techniczno-biurokratycznej + nazwa }\end{array}$ \\
\hline $\begin{array}{l}\text { 'brak wolności } \\
\text { obywatelskich' } \downarrow\end{array}$ & $\begin{array}{l}\text { niewolnicze podporzadkowanie władzy, bezwstydne/ślepe } \\
\text { posłuszeństwo }\end{array}$ \\
\hline 'aparat tajnej policji' $\downarrow$ & Gestapo, NKWD \\
\hline $\begin{array}{l}\text { 'stosującej terror } \\
\text { i przemoc, także } \\
\text { ludbójstwo' }\end{array}$ & $\begin{array}{l}\text { terror, czystki, niewolnictwo; orgia terroru i ucisku; brutalna } \\
\text { pięść; metody opanowania życia terrorem i brutalnego niszczenia; } \\
\text { straszliwe widmo terroru; fala barbarzyństwa i zakucie w kajdany } \\
\text { powszechnej niewoli; terror, gwalt i oszustwo; niewola i zagłada; } \\
\text { zbrodnia i okrucieństwo, duch ucisku i nietolerancji }\end{array}$ \\
\hline
\end{tabular}

Źródło: opracowanie własne.

Znakiem procesów związanych z kształtowaniem się znaczenia jest frekwencja użycia słowa - nieco większa niż w dwudziestoleciu, wyrażająca nie tylko świadomość i konkretne odniesienie do rzeczywistości, lecz także potrzebę nominacji tego, do czego doprowadziła wojna. $Z$ całą pewnością na podstawie bardzo reprezentatywnego materiału źródłowego można odnotować następujące kolokacje słowa totalizm — z użyciem tego rzeczownika i wyrazów pozostających wobec niego w substytucji znaczeniowej: 
Tabela 3. Kolokacje leksykalne odnoszące się do nazwy totalizm i jej derywatów

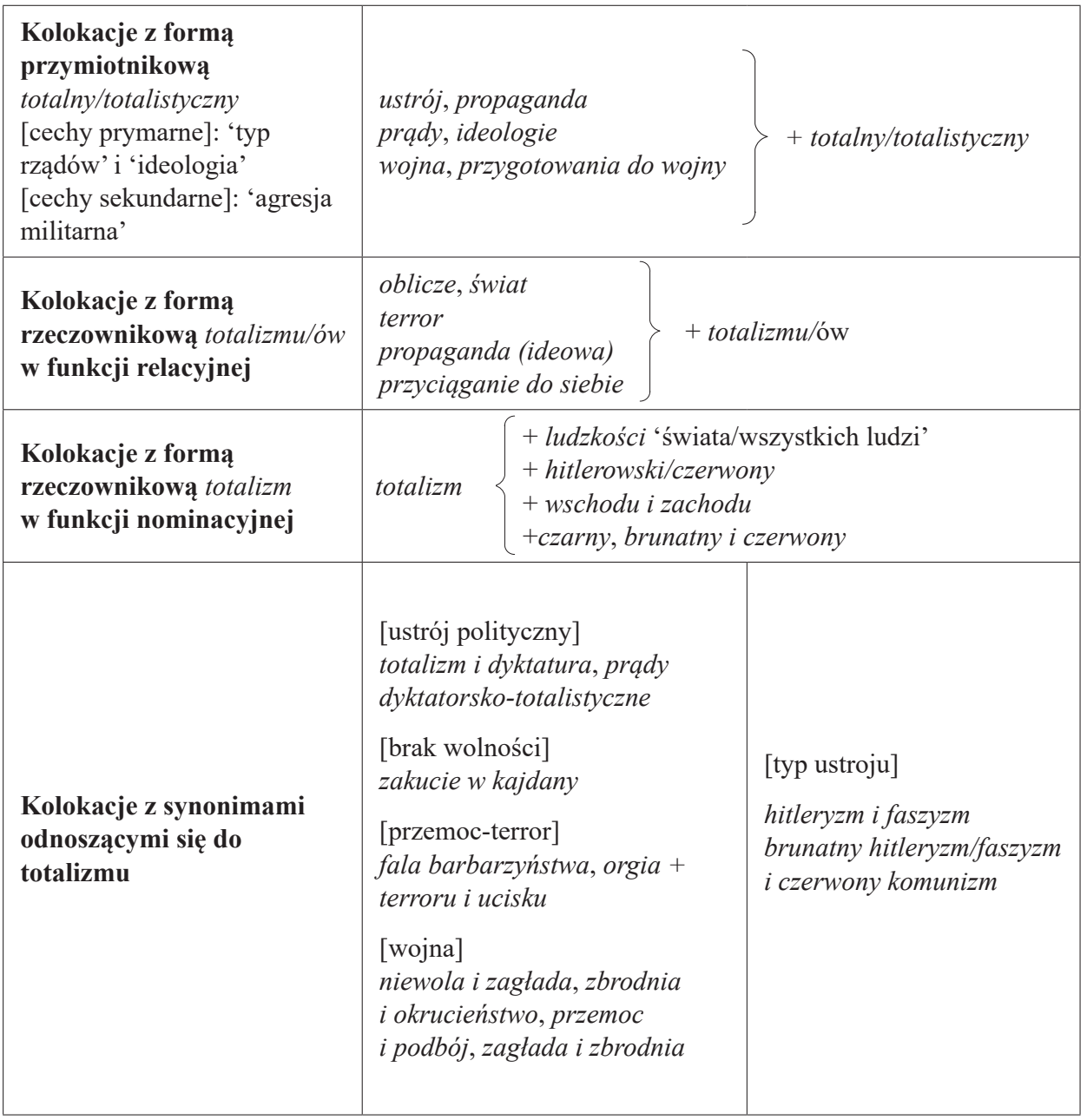

Źródło: opracowanie własne.

\section{Podsumowanie}

Artykuł opisuje źródła, a także dzieje pojęcia „totalitaryzm” w okresie drugiej wojny światowej. Jest to okres szczególny z dwóch powodów. Po pierwsze, słowa związane z polem leksykalno-semantycznym nazywającym reżimy i dyktatury, a także ideologie zorientowane na wprowadzenie rządów hegemonicznych dopiero nabierały swej wyrazistości znaczeniowej podczas wojny, czyli czasu brutalnych okupacyjnych rządów oraz agresji i propagandy — podstawowych narzędzi ich sprawowania. Publicystyczny obraz trzech europejskich, skrajnych dyktatur, 
odsłaniający się w dyskursie politycznym dwudziestolecia i włączany w różne konteksty aksjologiczne przed 1939 rokiem, utrwala się w okresie wojennym. Następuje stabilizacja znaczeniowa wielu wyrazów, gdyż referencja znaczeniowa ma wyrazisty charakter. Abstrakcyjny przed wojną koncept pojęciowy w czasie wojny się urealnia, także na poziomie podstawowej desygnacji. Po drugie, nazwa ta, choć obciążona, wyłania swoje synonimy lub substytuty znaczeniowe, ale zamyka się okres jej rozmycia aksjologicznego. Od tej pory pojęcie totalitaryzmu pojawia się wyłącznie w sferze antywartości, a wizje rzeczywistości totalnej rozmaicie oceniane w publicystyce dwudziestolecia międzywojennego - na tle zbiorowych doświadczeń wojennych i obrazu wojny zawartego w publicystyce konspiracyjnej wypełniają się ustabilizowanymi składnikami ocennymi.

Badany materiał odsłania jeszcze jedną właściwość — pojęcie totalitaryzmu otrzymuje swe najważniejsze składniki definicyjne utożsamiane z brutalnymi rządami, ograniczaniem swobód obywatelskich, przemocą stosowaną przez aparat policyjny, wreszcie — zagrożeniem praw, wolności, a nawet życia. W leksyce wojennej - na co wskazuje reprezentatywny materiał językowy wyekscerpowany z prasy konspiracyjnej wydawanej w rzeczywistości totalitarnej — używana jest wyłącznie forma wyrazowa przedwojenna, wypełniająca się nowymi składnikami definicyjnymi. Proces nazwotwórczy pojęcia w badanym okresie się rozpoczął, ale nie zakończył, gdyż dopiero po 1945 roku do uzusu weszła złożona postać leksemu totalitaryzm i motywowanych od niego derywatów.

\section{Bibliografia}

\section{Wydawnictwa leksykograficzno-encyklopedyczne}

Arct M. (1939), Podręczny stownik języka polskiego, Warszawa.

Encyclopedia Americana (1966), t. 1-30, New York.

Kopaliński W. (2004), Stownik wydarzeń, pojęć i legend XX wieku, Warszawa.

Kopaliński W. (1990), Stownik wyrazów obcych i zwrotów obcojęzycznych, Warszawa.

Stownik języka polskiego (1900-1927), red. J. Karłowicz, A. Kryński, W. Niedźwiedzki, t. 1-8,

Warszawa.

Stownik języka polskiego (1958-1969), red. W. Doroszewski, t. 1-11, Warszawa.

Stownik wyrazów obcych PWN (2002), red. E. Sobol, Warszawa.

Świat i Życie. Zarys encyklopedyczny współczesnej wiedzy i kultury (1939), red. Z. Łempicki, t. 1-5, Lwów-Warszawa.

Uniwersalny słownik języka polskiego PWN (2003), red. S. Dubisz t. 1-4, Warszawa.

Wielka ilustrowana encyklopedia powszechna, (1929-1937), Wyd. „Gutenberga” (Helge Fergo), t. 1-22, Kraków.

Wielki słownik języka polskiego IJP PAN, red. P. Żmigrodzki [wydawnictwo elektroniczne: https:// wsjp.pl]. 


\section{Opracowania}

Albright M. (2018), Faszyzm. Ostrzeżenie, przeł. K. Mironowicz, b.m.w.

Arendt H. (1986), Propaganda totalitarna, przeł. A. Rój, Warszawa.

Arendt H. (2008), Korzenie totalitaryzmu, przeł. D. Grinberg, Warszawa.

Bäcker R. (1992), Totalitaryzm. Geneza, istota, upadek, Toruń.

Bajerowa I. (red.) (1996), Język polski czasu drugiej wojny światowej, Warszawa.

Bankowicz M. (2010), Autorytaryzm i totalitaryzm - analiza porównawcza, [w:] Totalitaryzmy $X X$ wieku. Idee, instytucje, interpretacje, red. W. Kozub-Ciembroniewicz, H. Kowalska-Stus, B. Szlachta, M. Kiwior-Filo, Kraków.

Bartmiński J. (2008), Wartości i ich profile medialne, [w:] Ideologie w stowach i obrazach, red.

I. Kamińska-Szmaj, T. Piekot, M. Poprawa („Oblicza Komunikacji” 1), Wrocław.

Bartoszewski W. (1987), Na drodze do niepodległości, Paryż.

Besier G. (2010), How to explain why dictatorships are so fascinating?, [w:] Totalitaryzmy XX wieku. Idee, instytucje, interpretacje, red. W. Kozub-Ciembroniewicz, H. Kowalska-Stus, B. Szlachta, M. Kiwior-Filo, Kraków.

Besier G., Stokłosa K. (2009), Europa dyktatur, przeł. J. Hashold, Warszawa.

Bokszański Z. (2001), Stereotypy a kultura, Wrocław.

Butler J. (2010), Walczace stowa. Mowa nienawiści i polityka performatywu, przeł. A. Ostolski, Warszawa.

Cegieła A. (2014), Stowa i ludzie. Wprowadzenie do etyki słowa, Warszawa.

Chrobaczyński J. (2012), Dramatyczny rok 1943. Postawy i zachowania społeczeństwa polskiego w rozstrzygającym roku II wojny światowej, Rzeszów-Kraków.

Chrobaczyński J. (2015), Konteksty przełomu 1944-1945. Społeczeństwo wobec rozstrzygnięć. Postawy - zachowania - nastroje, Kraków.

Cytowska E. (1986), Szkice z dziejów prasy pod okupacją niemiecka (1939-1945), Warszawa-Łódź.

Dobek-Ostrowska B., Fras J., Ociepka B. (1999), Teoria i praktyka propagandy, Wrocław.

Doliński D., Gamian-Wilk M. (2014), Przestrzenie badań nad wpływem społecznym i manipulacja, [w:] Przestrzenie manipulacji, red. D. Doliński, M. Gamian-Wilk, Warszawa.

Dubisz S. (2007), Przekształcenia znaczeniowe słownictwa społeczno-politycznego w polszczyźnie XIX i XX (analiza danych leksykograficznych), [w:] Lingwistyka a polityka. Stownik pojęć politycznych i spolecznych krajów Europy Środkowej $i$ Wschodniej, red. S. Dubisz, J. Porayski-Pomsta, E. Sękowska, Warszawa.

Dubisz S., Porayski-Pomsta J., Sękowska E. (red.) (2004), Język, polityka, społeczeństwo. Stownik pojęć politycznych i społecznych krajów Europy Środkowej i Wschodniej, Warszawa.

Dubisz S., Porayski-Pomsta J., Sękowska E. (red.) (2007), Lingwistyka a polityka. Stownik pojęć politycznych i społecznych krajów Europy Środkowej i Wschodniej, Warszawa.

Fabiszak M. (2007), A Conceptual Metaphor Approach to War Discourse and its implications, Poznań.

Fras J. (2001), Język polityki, [w:] Najnowsze dzieje języków słowiańskich. Język polski, red. S. Gajda, Opole.

Fras J. (2006), Komunikacja polityczna. Wybrane zagadnienia gatunków i języka wypowiedzi, Wrocław.

Głowiński M. (1996), O dyskursie totalitarnym, [w:] O zagrożeniach i bogactwie polszczyzny, red. J. Miodek, Wrocław.

Głowiński M. (2002), Mowa agresji, [w:] Człowiek i agresja. Głosy o nienawiści i przemocy. Ujęcie interdyscyplinarne, red. S. Amsterdamski, Warszawa.

Głowiński M. (2007), Retoryka nienawiści, „Nauka”, nr 2.

Głowiński T. (2000), O nowy porzadek europejski. Ewolucja hitlerowskiej propagandy politycznej wobec Polaków w Generalnym Gubernatorstwie 1939-1945, Wrocław. 
Golka B. (1975), Prasa konspiracyjna ruchu ludowego, Białystok.

Gross J.T. (2002), Totalitaryzm [hasło w:] Encyklopedia socjologii, t. 4., red. Z. Bokszański i in., Warszawa.

Habielski R. (2009), Polityczna historia mediów w Polsce w XX wieku, Warszawa.

Hertz A. (1994), Szkice o totalitaryzmie, wyboru dokonał J. Garewicz, wstępem opatrzył W. Lamentowicz, Warszawa.

Holzer J. (2008), Europa wojen 1914-1945, Warszawa.

Ignatowicz A. (2011), Formy i metody oddziaływania propagandowego Armii Krajowej na spoleczeństwo polskie w drugiej połowie 1943 roku, [w:] Komunikowanie się Polaków w okresie II wojny światowej, red. K. Stępnik, M. Rajewski, Lublin.

Jaeschke A. (2002), Totalni sasiedzi Polski w publicystyce politycznej 1931-1939, Kraków.

Jakubowska-Branicka I. (2013), O dogmatach narracyjnych. Studium nienawiści, Warszawa.

Jarecka U. (2008), Propaganda słusznej wojny. Media wizualne XX wieku wobec konfliktów zbrojnych, Warszawa.

Jarowiecki J. (1980a), Prasa w Polsce 1939-1945, [w:] Prasa polska 1939-1945, red. J. Łojek, Warszawa.

Jarowiecki J. (1980b), Konspiracyjna prasa w Krakowie w latach okupacji hitlerowskiej 19391945, Kraków.

Jędrzejko E. (1996), Język satyry politycznej, [w:] Język polski okresu drugiej wojny światowej, red. I. Bajerowa, Warszawa.

Kamińska-Szmaj I. (1994), Judzi, zohydza, ze czci odziera. Język propagandy politycznej w prasie 1919-1923, Wrocław.

Kamińska-Szmaj I. (2004), Propaganda, perswazja, manipulacja - próba uporządkowania pojęć, [w:] Manipulacja w języku, red. P. Krzyżanowski, P. Nowak, Lublin.

Kamińska-Szmaj I. (2006), Rzeczowniki z przyrostkiem -izm/ -yzm w języku polityki, „Rozprawy Komisji Językowej WTN" 23.

Kamińska-Szmaj I. (2007), Agresja językowa w życiu publicznym. Leksykon inwektyw politycznych 1918-2000, Wrocław.

Kamińska-Szmaj I. (2013), Komunikacja polityczna — język, styl, dyskurs, [w:] Style wspótczesnej polszczyzny. Przewodnik po stylistyce polskiej, red. E. Malinowska, J. Nocoń, U. Żydek-Bednarczuk, Opole.

Kamińska-Szmaj I. (2014), Zdobywanie władzy - zawłaszczanie języka (akcje propagandowe poprzedzające powstanie PRL), [w:] Język polityki - historia i współczesność, red. I. Kamińska-Szmaj, T. Piekot, M. Poprawa („Oblicza Komunikacji” 7), Wrocław.

Kamińska-Szmaj I. (2015), U źródet politycznego dyskursu dominującego w czasach PRL, [w:] Dyskurs i jego odmiany, red. B. Witosz, K. Sujkowska-Sobisz, E. Ficek, Katowice.

Kamińska-Szmaj I. (2017), Język polskiej lewicy. Od Wielkiego Proletariatu do końca PRL, Wroclaw.

Kamińska-Szmaj I., Piekot T., Poprawa M. (red.) (2008), Ideologie w słowach i obrazach („Oblicza Komunikacji” 1), Wrocław.

Karamańska M. (2007), Słownictwo polityczne Drugiej Rzeczypospolitej w latach 1926-1939, Kraków.

Karpiński J. (1984), Mowa do ludu. Szkice o języku polityki, London.

Karwat M. (2006), O złośliwej dyskredytacji. Manipulowanie wizerunkiem przeciwnika, Warszawa.

Karwat M. (2008), Cechy myślenia ideologicznego, [w:] Ideologie w stowach i obrazach, red. I. Kamińska-Szmaj, T. Piekot, M. Poprawa („Oblicza Komunikacji” 1), Wrocław.

Karwat M. (2014a), Rewizje obiegowych pojęć manipulacji, [w:] Przestrzenie manipulacji, D. Doliński, M. Gamian-Wilk, Warszawa.

Karwat M. (2014b), Podstawy socjotechniki dla politologów i nie tylko, Warszawa.

Kershaw I. (2016), Do piekta i z powrotem, przeł. A. Romanek, Kraków. 
Klemperer V. (1989), LTI: notatnik filologa, przeł. i oprac. J. Zychowicz, Kraków.

Kleszczowa K. (1996), Odbicie rzeczywistości wojennej i okupacyjnej w leksyce języka ogólnego, [w:] Język polski czasu drugiej wojny światowej (1939-1945), red. I. Bajerowa, Warszawa.

Kołtunowski P. (1990), Strategie propagandy hitlerowskiej w Generalnym Gubernatorstwie na podstawie „Krakauer Zeitung” (1939-1945). Studium historyczno-filologiczne, Lublin.

Kołtunowski P. (1995), Metody ksztaltowania morale wojennego na podstawie tekstów przemówień ministra propagandy III Rzeszy Josepha Goebbelsa z okresu drugiej wojny światowej: aspekt argumentacyjno-psychologiczny, Lublin.

Korboński S. (2008), Polskie Państwo Podziemne. Przewodnik po Podziemiu z lat 1939-1945, Warszawa.

Korzeniowski K. (2010), Paranoja polityczna. Charakterystyka zjawiska i metody jego pomiaru, „Przegląd Polityczny”, nr 2.

Kozub-Ciembroniewicz W. (2010), Bolszewizm, faszyzm włoski, nacjonalizm w polskiej historiografii (wybór analiz i intepretacji), [w:] Totalitaryzmy XX wieku. Idee, instytucje, interpretacje, red. W. Kozub-Ciembroniewicz, H. Kowalska-Stus, B. Szlachta, M. Kiwior-Filo, Kraków.

Kula H.M. (2005), Propaganda współczesna. Istota - właściwości, Torun.

Kwapień E. (2004), Zmiany znaczeniowe polskiego stownictwa politycznego i społecznego (XIX i XX wiek), [w:] Język, polityka, społeczeństwo. Słownik pojęć politycznych i społecznych krajów Europy Środkowej i Wschodniej, red. S. Dubisz, J. Porayski-Pomsta, E. Sękowska, Warszawa.

Kwapień E. (2007), Pole tematyczne nazw typów ustrojów i ich cech w leksykografii polskiej od początku XIX wieku do początku XXI wieku, [w:] Lingwistyka a polityka. Stownik pojęć politycznych i społecznych krajów Europy Środkowej i Wschodniej, red. S. Dubisz, J. Porayski-Pomsta, E. Sękowska, Warszawa.

Lakoff G. (2003), Metafory i wojna. System metafor użyty, by usprawiedliwić wojnę w Zatoce Perskiej, „Etnolingwistyka”, nr 19.

Lewandowska S. (1992), Prasa okupowanej Warszawy 1939-1945, Warszawa 1992.

Linde-Usiekniewicz J. (2015), Teoria relewancji jako narzędzie opisu ,mowy nienawiści”, „Studia Pragmalingwistyczne" 7.

Mazur M. (2011), Język polityki PPR podczas II wojny światowej, [w:] Komunikowanie się Polaków w okresie II wojny światowej, red. K. Stępnik, M. Rajewski, Lublin.

Müller J.-W. (2016), Przeciw demokracji. Idee polityczne XX wieku w Europie, przeł. J. Majmurek, Warszawa.

Neumann F. (2016), Behemot. Narodowy socjalizm. Ustrój i funkcjonowanie 1933-1944, przeł. J. Giebułtowski, Warszawa.

Niewiara A. (2010), Ksztalty polskiej tożsamości. Potoczny dyskurs narodowy w perspektywie etnolingwistycznej (XVI--XX wiek), Katowice.

Nijakowski L.M. (2008), Mowa nienawiści w świetle teorii dyskursu, [w:] Analiza dyskursu w socjologii i dla socjologii, red. A. Horolets, Toruń.

Nijakowski L.M. (2013), Rozkosz zemsty. Socjologia historyczna mobilizacji ludobójczej, Warszawa.

Nowak P. (2008), Retoryka a propaganda polityczna, [w:] Retoryka, red. M. Barłowska, A. Budzyńska-Daca, P. Wilczek, Warszawa.

Olszewska-Dyoniziak B. (1999), Antropologia totalitaryzmu europejskiego XX wieku, Wrocław.

Olszewski H. (2010), O roli ideologii wroga w ksztaltowaniu się systemów totalitarnych, [w:] Totalitaryzmy XX wieku. Idee, instytucje, interpretacje, red. W. Kozub-Ciembroniewicz, H. Kowalska-Stus, B. Szlachta, M. Kiwior-Filo, Kraków.

Orwell G. (2013), Anglicy i inne eseje, przeł. B. Zborski, Warszawa 2013.

Ostaszewska D. (1996), Wpływy rosyjskie i ukraińskie, [w:] Język polski czasu drugiej wojny światowej (1939-1945), red. I. Bajerowa, Warszawa.

Pacuła J. (2012), Stowa w natarciu. Metaforyka militarna $w$ dyskursie publicznym, „Zeszyty Prasoznawcze", nr 3. 
Piekot T., Poprawa M., Sojka-Masztalerz H. (red.) (2016), Medialne i propagandowe oblicza wojny, („Oblicza Komunikacji” 9), Wrocław.

Pipes R. (2005), Rosja bolszewików, przeł. W. Jeżewski, Warszawa.

Pipes R. (2011), Polska sowietologia do 1939 roku, „Studia nad Faszyzmem i Zbrodniami Hitlerowskimi" 23.

Pisarek W. (2004), Wybory stów sztandarowych jako kryterium stratyfikacji społeczeństwa, [w:] Język w kręgu wartości, red. J. Bartmiński, Lublin.

Pisarek W. (2008), Wstep do nauk o komunikowaniu, Warszawa.

Polkowska L. (2015), Język prawicy, Warszawa.

Połowniak-Wawrzonek D. (2008), Związki frazeologiczne współczesnego języka polskiego motywowane sytuacja walki (zbrojnej), Kielce.

Poprawa M. (2016a), Inwektywy czasów II wojny światowej. Językowe środki obrażania przeciwnika/wroga politycznego w prasie konspiracyjnej lat 1939-1945, [w:] Medialne i propagandowe oblicza wojny, red. T. Piekot, M. Poprawa, H. Sojka-Masztalerz („Oblicza Komunikacji” 9), Wrocław.

Poprawa M. (2016b), Plotka i pogłoska jako specyficzny akt komunikacji wojennej, [w:] Lingua et gaudium. Księga jubileuszowa ofiarowana Profesorowi Janowi Miodkowi, red. M. Zaśko-Zielińska, M. Misiak, J. Kamieniecki, T. Piekot, Wrocław.

Poprawa M. (2017), Prasa konspiracyjna $w$ stużbie kontrpropagandy - funkcje, cele, zjawiska językowe (na przyktadzie gazet podziemnych 1939-1945), [w:] Obrazy wojny w mediach, pamięci i języku, red. H. Sojka-Masztalerz, M. Poprawa, T. Piekot („Oblicza Komunikacji” 10), Wrocław.

Pratkanis A., Aronson E. (2008), Wiek propagandy. Używanie i nadużywanie perswazji na co dzień, przeł. J. Radzicki, M. Szuster, oprac. K. Skarżyńska, Warszawa.

Robins R.S., Post J.M. (2007), Paranoja polityczna. Psychologia nienawiści, przeł. H. Jankowska, Warszawa.

Ryszka F. (1985), Państwo stanu wyjątkowego, Wrocław.

Sękowska E. (2004), Wybrane problemy opisu polskiego słownictwa dotyczacego pojęć politycznych i społecznych, [w:] Język, polityka, społeczeństwo. Stownik pojęć politycznych i społecznych krajów Europy Środkowej i Wschodniej, red. S. Dubisz, J. Porayski-Pomsta, E. Sękowska, Warszawa.

Sękowska E. (2007), Metodologiczne problemy opisu słownictwa społeczno-politycznego w polszczyźnie XIX i XX wieku, [w:] Lingwistyka a polityka. Stownik pojęć politycznych i społecznych krajów Europy Środkowej i Wschodniej, red. S. Dubisz, J. Porayski-Pomsta, E. Sękowska, Warszawa.

Snyder T. (2017), O tyranii. Dwadzieścia lekcji z dwudziestego wieku, przeł. B. Pietrzyk, Kraków.

Sojka-Masztalerz H., Poprawa M., Piekot T. (red.) (2017), Obrazy wojny w mediach, pamięci i języ$k u$ („Oblicza Komunikacji” 10”), Wrocław.

Stelmach K. (2014), Mediatyzacja propagandy - propagandyzacja mediów: wczoraj i dziś, „Zeszyty Prasoznawcze", nr 2.

Stępnik K., Rajewski M. (red.) (2011), Komunikowanie się Polaków w okresie II wojny światowej, Lublin.

Stomma L. (2014), Antropologia wojny, Warszawa.

Szarota T. (1988), Okupowanej Warszawy dzień powszedni, Warszawa.

Totalitaryzmy XX wieku. Idee, instytucje, interpretacje (2010), red. W. Kozub-Ciembroniewicz, H. Kowalska-Stus, B. Szlachta, M. Kiwior-Filo, Kraków.

Traverso E. (2011), Europejskie korzenie przemocy nazistowskiej, przeł. A. Czarnecka, Warszawa.

Wasilewski J., Skibiński A. (2008), Prowadzeni słowami. Retoryka motywacji w komunikacji publicznej, Warszawa.

Welch D. (2003), Introduction, [w:] Propaganda and Mass Persuasion: A Historical Encyclopedia - 1500 to the Present, red. N. J. Cull, D. Holbrook Culbert, David Welch, ABC CLIO. 
Winstone M. (2015), Generalne Gubernatorstwo. Mroczne serce Europy Hitlera, przeł. T. Fiedorek, Poznań.

Wodak R. (2008), Dyskurs populistyczny: retoryka wykluczenia a gatunki języka pisanego, [w:] Krytyczna analiza dyskursu. Interdyscyplinarne podejście do komunikacji społecznej, red.

A. Duszak, N. Fairclough, Kraków.

Wodak R. (2011), Badania nad dyskursem — ważne pojęcia i terminy, [w:] Jakościowa analiza dyskursu w naukach społecznych, red. R. Wodak i M. Krzyżanowski, Warszawa.

Wojsław J. (2017), Figura wroga $w$ ideologii $w$ ideologii i propagandzie XX-wiecznych totalitaryzmów - przyczynek do dyskusji, „Media - Biznes - Kultura. Dziennikarstwo i Kultura Społeczna", nr 2.

Wolińska O. (1992), Nowomowa a język propagandy wojennej, „Postscriptum”, nr 5.

Wolińska O. (1996), Język polski w walce, [w:] Język polski czasu drugiej wojny światowej, red. I. Bajerowa, Warszawa.

Woźniakowski K. (1997), W kręgu jawnego piśmiennictwa literackiego Generalnego Gubernatorstwa (1939-1945), Kraków.

Woźniakowski K. (2005), Niemiecka polskojęzyczna prasa „,gadzinowa” czasów II wojny światowej 1939-1945, [w:] idem, Prasa, kultura, wojna. Seria druga, Kraków.

Woźniakowski K. (2014), Polskojęzyczna prasa gadzinowa czasów okupacji hitlerowskiej, Kraków. Wyka K. (2008), Życie na niby, Kraków.

Zemszał P. (2008), Ideologem w dyskursie ideologicznym, [w:] Ideologie w stowach i obrazach, red. I. Kamińska-Szmaj, T. Piekot, M. Poprawa („Oblicza Komunikacji” 1), Wrocław.

Zemszał P. (2016), Ojciec, wódz, nauczyciel. Nominacje językowe dotyczace Stalina w sowieckim dyskursie ideologicznym $w$ okresie powojennym, Toruń.

\section{Totalitarianism as a collective experience and conceptualisation in language: The language image of the concept in the underground press and the language of political propaganda of the Second World War}

\section{Summary}

The article consists of two parts. In the first part, the author of the article describes the history of the concept of totalitarianism and words used in the semantic field of that lexeme. In the theoretical fragments, the author describes the phenomenon of lexicographical and semantic researches on the word totalitarianism (also presents a history of that important word from the political vocabulary). The second part of the article is empirical. The author presents examples of how lexical meanings of totalitarianism were used in a very important period of history and a very important period for that word. The article describes the process of beginning to name totalitarianism and the semantic process of that concept during the Second World War.

Keywords: totalitarianism, war-time political discourse, language of political propaganda of the Second World War 